\title{
RESídUOS DE DELTAMETRINA, MALATION E PIRIMIFóS-METIL EM GRÃOS DE MILHO E SUA AÇÃO SOBRE \\ Rhyzopertha dominica (Fabr., 1792) \\ (COLEOPTERA - BOSTRICHIDAE)
}

\author{
BERNARDO ALLEONI \\ (Engenheiro Agrônomo)
}

Orientador: Prof. Dr. GILBERTO CASADEI DE BAPTISTA

Tese apresentada à Escola Superior de Agricultura "Luiz de Queiroz", da Universidade de São Paulo, para obtenção do título de Doutor em Ciências. Área de concentração: Entomologia.

PIRACICABA

ESTADO DE SÃO PAULO - BRASIL 


\section{CATALOEACAO NA PURLICAGAO}

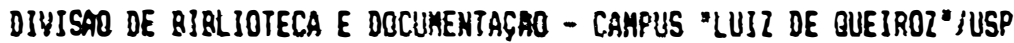

Alleoni, Bernardo

Residuos de deltametrina, malation e piriejfos - netil ea graos de ailho z suas afoto sobre Rhyzopertha doninica (Fabr., 1392 ) (Coleaptera 8ostrichidae 1. Piracicaba, 1995.

80p.

Tese - ESALQ

Bibljografia

1. Mitho arkaienado - Praga - Controle 2. Milho arazenado - Residuo de pescada - Deterasnagro 1. Escola Supersor de Agricultura Lusz de Quesroz, firacicaba, $S P_{i}$. 
RESÍdUOS DE DELTAMETRINA, MALATION E PIRIMIFÓS-METIL

EM GRÃOS DE MILHO E SUA AÇÃO SOBRE Rhyzopertha dominica (Fabr., 1792)

(COLEOPTERA - BOSTRICHIDAE)

\author{
BERNARDO ALLEONI
}

Aprovada em: 22/03/95

Comissão Julgadora:

Prof. Dr. Gilberto Casadei de Baptista

Prof. Dr. Celso Omotto

Prof Dr. Antonio Luiz Fancelli

Prof. Dr. Joaquim G. Machado Neto

Prof Dr. Ricardo P. Lima Carvalho
ESALQ/USP

ESALQ/USP

ESALQ/USP

UNESP/Jaboticabal

UNESP/Jaboticabal

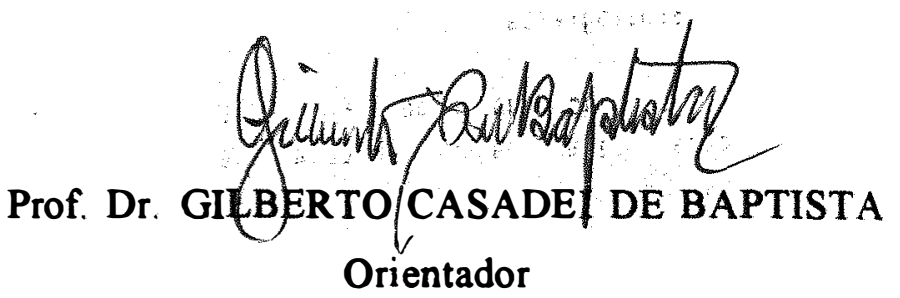


A meus pais

ANTONIO E ANTONIA

OFEREÇO.

A minha esposa

ELIZA BETE

e filhos

JÉSSICA

IAMILE

BERNARDO

REBECA

DEDICO. 


\section{AGRADECIMENTOS}

Ao Prof. Dr. Gilberto Casadei de Baptista, pela orientação e apoio no preparo e execução deste trabalho.

Aos Professores do Departamento de Entomologia da ESALQ/USP, pelos ensinamentos durante o curso.

Ao Conselho Nacional de Desenvolvimento Científico e Tecnológico - CNPq pela concessão das bolsas de estudo no decorrer do curso.

À Prof. Dr. Marinéia Lara Haddad e Dr. Celso Omoto pela orientação na análise estatística e revisão do summary, respectivamente.

Ao Sr. Edson Maciel, estagiários e funcionários do Setor de Toxicologia de Inseticidas pela colaboração nas análises laboratoriais.

Às bibliotecárias Kátia e Eliana pela correção das Referências Bibliográficas e demais funcionários da Biblioteca Central pela colaboração.

Ao Sr. Jorge Luiz Diorio pelos serviços de digitação.

Aos colegas do Curso de Pós-Graduação, pela amizade e incentivo no decorrer do curso.

E a todos que, direta ou indiretamente, contribuiram para a realização deste trabalho. 


\section{ÍNDICE}

Página

RESUMO . . . . . . . . . . . . . . . . . . . . . . .

SUMMARY . . . . . . . . . . . . . . . . . . . . . XV

1. INTRODUÇÃO . . . . . . . . . . . . . . . . . . . . . . . . . 1

2. REVISÃO DA LITERATURA _. . . . . . . . . . . . . . 4

2.1. Comportamento de resíduos de inseticidas em grãos armazenados . $\quad 4$

2.1.1. Resíduos de inseticidas em grãos armazenados . . . . . . . 9

2.2. Características da deltametrina . . . . . . . . . . . . . . . 13

2.3. Características do malation . . . . . . . . . . . . . . . . 15

2.4. Características do pirimifós-metil . . . . . . . . . . . . 17

2.5. Controle de pragas dos grãos armazenados . . . . . . . . . . . 19

2.6. Aspectos bioecológicos e danos de Rhyzopertha dominica e outros insetos em grãos armazenados . . . . . . . . . . . . 23

3. MATERIAL E MÉTODOS . . . . . . . . . . . . . . . . . . . . . 26

3.1. Experimento de laboratório . . . . . . . . . . . . . . . . . 26

3.2. Atividade residual dos inseticidas sobre os adultos de $\mathbf{R}$. dominica . 27

3.3. Limites de deteç̧ão, porcentagem de recuperação e descrição dos métodos de análise de deltametrina, malation e pirimifós-metil em grãos de milho . . . . . . . . . . . . . . . . . . . . . 28

3.3.1. Análise de resíduos de malation e pirimifós-metil . . . . . . $\quad 29$

3.3.1.1. Reagentes . . . . . . . . . . . . . . . 29

3.3.1.2. Aparelhos, vidrarias e outros materiais ... . . . 30

3.3.1.3. Marcha analítica . . . . . . . . . . . . . 31 
3.3.2. Análise de resíduos de deltametrina . . . . . . . . . 34

3.3.2.1. Reagentes . . . . . . . . . . . . . . 35

3.3.2.2. Aparelhos, vidrarias e outros materiais . . . . . 35

3.3.2.3. Marcha analítica . . . . . . . . . . . 36

4. RESULTADOS E DISCUSSÃO . . . . . . . . . . . . . . . . . . 39

4.1. Resíduos de deltametrina em grãos de milho armazenados - . . . . 39

4.2. Resíduos de malation em grãos de milho armazenados . . . . . . . 42

4.3. Resíduos de pirimifós-metil em grãos de milho armazenados . . . 45

4.4. Considerações gerais sobre o comportamento dos resíduos dos inseticidas . . . . . . . . . . . . . . . . . . . . . . 47

4.5. Análise de umidade de grãos de milho . . . . . . . . . . . . 50

4.6. Efeito de deltametrina, malation e pirimifós-metil sobre os adultos de Rhyzopertha dominica . . . . . . . . . . . . . . . . 53

4.7. Danos causados por Sitophilus zeamais e Rhyzopertha dominica em grãos de milho armazenados . . . . . . . . . . . . . . . . . . . 60

4.8. Limite de deteç̧ão e porcentagem de recuperação dos métodos . . $\quad 63$

5. CONCLUSÕES . . . . . . . . . . . . . . . . . . . . . . . . 69

REFERÊNCIAS BIBLIOGRÁFICAS . . . . . . . . . . . . . 71 


\section{LISTA DE FIGURAS}

FIGURA N.

Página

1. Fórmula estrutural plana de deltametrina . . . . . . . . . . 14

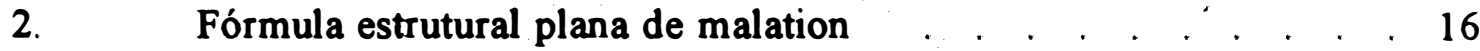

3. Fórmula estrutural plana de pirimifós-metil _. . . . . . . . 17

4. Curvas de degradação de resíduos de deltametrina em grãos de milho

5. Curvas de degradação de resíduos de malation em grãos de milho

6. Curvas de degradação de resíduos de pirimifós-metil em grãos de milho

7. Temperaturas máximas, mínimas e precipitação pluvial médias, nos meses de janeiro a dezembro de 1993, no município de Piracicaba-SP, com respectivos dias de amostragem

8. Resíduos médios de deltametrina, malation e pirimifós-metil e mortalidade de $R$. dominica em grão de milho

9. Danos (\%) de Sitophilus zeamais em grãos de milho

10. Danos (\%) de Rhyzopertha dominica em grãos de milho 
11. Cromatogramas: a) Amostra testemunha; b) Padrão analítico de deltametrina (200 pg); c) Amostra de grãos de milho fortificada com deltametrina $(0,05 \mathrm{ppm})$. . . . . . . . . . . . . 65

12. Cromatogramas: a) Amostra testemunha; b) Padrão analítico de malation (100 pg); c) Amostra de grãos de milho fortificada com malation $(0,01$ ppm) . . . . . . . . . . . . . . . . 66

13. Cromatogramas: a) Amostra testemunha; b) Padrão analítico de pirimifós-metil (100 pg); c) Amostra de grãos de milho fortificada com pirimifós-metil $(0,02 \mathrm{ppm})$ 


\section{LISTA DE TABELAS}

TABELA N..$^{\circ}$

Página

1. Valores de meias-vida de persistência de alguns defensivos agrícolas em grãos armazenados . . . . . . . . . . . . . . . . . 6

2. Niveis de tolerâncias máximas legais e ingestão diária aceitável de resíduo de defensivos agrícolas em produtos armazenados

3. Resíduos de deltametrina em grãos de milho tratados com

0,5 e $1,0 \mathrm{ppm}$ do inseticida, analisados mensalmente até 180 dias após aplicação

4. Resíduos de malation em grãos de milho tratados com 20 e 40 ppm do inseticida, analisados mensalmente até 180 dias após aplicação

5. Resíduos de pirimifós-metil em grãos de milho tratados com 6 e 12 ppm do inseticida, analisados mensalmente até 180 dias após aplicação

6. Resultados de análise de umidade de grãos de milho

7. Porcentagem de mortalidade de adultos de Rhyzopertha dominica, avaliada 15 dias após infestação

8. Residuos médios de deltametrina, malation e pirimifós-metil em grãos de milho e porcentagens de mortalidade média de Rhyzopertha dominica 
9. Peso (g) de grãos de milho antes e depois da infestação com Sitophilus zeamais e porcentagem (\%) de danos observadas e corrigidas, após 120 dias . . . . . . . . . . . . . . . . 61

10. Peso (g) de grãos de milho antes e depois da infestação com Rhyzopertha dominica e porcentagem (\%) de danos observadas e corrigidas, após 120 dias

11. Porcentagem (\%) de recuperação de deltametrina, malation e pirimifós-metil pelos métodos de análise de resíduos em amostras de grãos de milho fortificadas . . . . . . . . . . . . . . . 64 


\section{RESídUOS DE DELTAMETKINA, MALATION E PIRIMIFÓS-METIL EM GRÃOS DE MILHO E SUA AÇÃO SOBRE Rhyzopertha dominica (Fabr., 1792) (COLEOPTERA - BOSTRICHIDAE)}

Autor: Bemardo Alleoni

Orientador. Prof. Dr. Gilberto Casadei de Baptista

\section{RESUMO}

Foi estudado o comportamento residual de deltametrina (K-obiol 25 CE); malation (Malatol $50 \mathrm{CE}$ ) e pirimifós-metil (Actellic $500 \mathrm{CE}$ ) em grãos de milho; o efeito deles sobre Rhyzopertha dominica (Fabr., 1792) (Coleoptera - Bostrichidae) e a importância dos danos causados pela espécie em milho, comparada com a de Sitophilus zeamais (Mots., 1855) (Coleoptera - Curculionidae).

Os experimentos foram conduzidos no Laboratório de Toxicologia de Inseticidas do Departamento de Entomologia da Escola Superior de Agricultura "Luiz de Queiroz", da Universidade de São Paulo, em Piracicaba-SP, no período de 06/03/93 a 06/09/93.. Os inseticidas foram testados em duas dosagens cada um, aplicando-se 5 litros de calda preparada por tonelada de grãos, de modo a alcançar concentrações de: deltametrina 0,5 e $1,0 \mathrm{ppm}$; malation 20 e $40 \mathrm{ppm}$ e pirimifós-metil 6 e $12 \mathrm{ppm}$. 0 
delineamento experimental foi inteiramente ao acaso, com 3 repetições. As amostras foram tomadas mensalmente durante um período de 180 dias; para quantificações de resíduos, de infestação de adultos de $R$. dominica e para análise de umidade dos grãos.

O método analítico para a quantificação de resíduos do piretróide constou de extração com uma mistura de hexano + éter etílico, seguida de partição com hexano, limpeza em coluna cromatográfica de florisil eluída com mistura de hexano + éter etílico e concentração dos extratos. $\mathrm{O}$ método para a quantificação dos fosforados procedeuse pela extração com acetonitrila, seguida de partição com diclorometano, limpeza em coluna cromatográfica de carvão ativado eluída com uma mistura de acetonitrila + benzeno e concentração dos extratos. A determinação quantitativa foi realizada em cromatógrafo a gás, equipado com detector de ionização de chama alcalina (DICA), para os fosforados e detector de captura de elétrons (DCE, $\mathrm{Ni}^{63}$ ), para o piretróide.

Os limites de deteç̧ão de resíduos pelos métodos de análise dos fosforados e piretróide foram 0,01 e 0,05 ppm, respectivamente. As porcentagens de recuperação variaram de 81 a $111 \%$ para deltametrina; 90 a $129 \%$ para malation e 99 a $129 \%$ para pirimifós-metil.

As análises dos resíduos feitas aos 180 dias após a aplicação revelaram degradações de 69 e $73 \%$ dos depósitos obtidos das dosagens de 0,5 e 1,0 ppm de deltametrina e períodos de meias-vida de 107 dias para ambas as dosagens. Os depósitos das dosagens de 20 e 40 ppm de malation foram degradados em 73 e $70 \%$ no mesmo periodo e apresentaram periodos de meias-vida, de 109 e 110 dias, respectivamente. Dos depósitos das dosagens de 6 e 12 ppm de pirimifós-metil, houve degradação, em ambas, 
de $75 \%$ em ambas dosagens no mesmo período e apresentaram períodos de meias-vida de 130 e 93 dias, respectivamente.

O controle de $R$. dominica foi efetivo somente com deltametrina, obtendo-se $100 \%$ de mortalidade para as duas dosagens utilizadas, mesmo aos 180 dias após o tratamento. Os fosforados foram inexpressivos no controle da praga desde o início do tratamento.

Os danos causados por $S$. zeamais em grãos de milho foram aproximadamente cinco vezes maiores do que aqueles produzidos por $R$. dominica, sendo 16 e $3 \%$, as perdas de peso dos grãos, respectivamente, 120 dias após a infestação.

Os limites máximos de resíduos e intervalos de segurança estabelecidos pela legislação em grãos de milho são: $1,0 \mathrm{mg} / \mathrm{kg}$ e 30 dias, para deltametrina: $8 \mathrm{mg} / \mathrm{kg}$ e 60 dias para malation e $10 \mathrm{mg} / \mathrm{kg}$ e 30 dias para pirimifós-metil. Segundo os resultados obtidos, é necessário melhor estudo e avaliação da legislação em relação a estes parâmetros toxicológicos, pois a dosagem de deltametrina recomendada para o controle de pragas é igual ao limite máximo de resíduos; o intervalo de segurança encontrado para malation foi cerca de 2,5 vezes superior ao estabelecido pela legislação e o limite máximo de resíduos de pirimifós-metil é superior à dosagem recomendada para aplicação em grãos. 


\section{RESIDUE ANALYSIS OF DELTAMETHRIN, MALATHION AND PIRIMIPHOS-METHYL IN STORED CORN AND THEIR ACTIVITY ON Rhyzopertha dominica (Fabr., 1792) (COLEOPTERA - BOSTRICHIDAE)}

Author: Bemando Alleoni

Advisor: Prof. Dr. Gilberto Casadei de Baptista

\section{SUMMARY}

Residue analysis of deltamethrin (K-obiol $25 \mathrm{CE}$ ), malathion (Malatol $500 \mathrm{CE}$ ) and pirimiphos-methyl (Actellic $500 \mathrm{CE}$ ) in stored corn and their activity on Rhyzopertha dominica (Fabr., 1792) (Coleoptera - Bostrichidae) were evaluated in this study. The importance of this species was compared with Sitophilus zeamais (Mots., 1855) (Coleoptera - Curculionidae).

The experiments were conducted at Toxicology Laboratory of Department of Entomology, Escola Superior de Agricultura "Luiz de Queiroz", Universidade de São Paulo, Piracicaba-SP. Each insecticide was tested in two dosages as follow: deltamethrin at 0.5 and $1.0 \mathrm{ppm}$, malathion at 20 and $40 \mathrm{ppm}$, and pirimiphosmethyl at 6 and $12 \mathrm{ppm}$. The experimental design was completely randomized with three replicates. The amount of 5 liters of prepared solution was applied per ton of grain. Samples of each treatment were taken monthly during a 6-month period in order to analyse 
the insecticide residues, infest with adults of $R$. dominica and determine the humidity content in the grain.

The residue analysis for the pyrethroid consisted of extraction with a mixture of hexane + ethyl ether followed by partition with hexane, clean-up by florisil column chromatography eluted with a mixture of hexane + ethyl ether, and concentration of the extracts. For the organophosphates, extraction was done with acetonitrile followed by partition with dichloromethane, clean-up in a activated charcoal, column chromatography and concentration of the extracts. The quantitative measurements of the residues were determined by gas chromatography, equipped with alcali flame ionization detector for the organophosphates and with electron capture detector (ECD, $\mathrm{Ni}^{63}$ ) for the pyrethroid.

The detection limits for the organophosphates and pyrethroid were 0.01 and $0.05 \mathrm{ppm}$, respectively. The percent of recovery varied from 81 to $111 \%$ for deltamethrin, 90 to $129 \%$ for malathion and 99 to $129 \%$ for pirimiphos-methyl.

Residue analysis conducted at 180 days after treatment showed degradation of 69 and $73 \%$ and half-lives both of 107 days at rates of 0.5 and $1.0 \mathrm{ppm}$ of deltamethrin. For malathion at 20 and 40 ppm, the degradation was 73 and $70 \%$ and halflives of 109 and 110 days, respectively. And for pirimiphos-methyl at 6 and $12 \mathrm{ppm}$, the degradation was $75 \%$ at both rates and half-lives of 130 and 93 days, respectivelly.

Effective control of $R$. dominica was obtained only with deltamethrin. Both rates of this product gave $100 \%$ mortality even at 180 days after treatment. Control of this pest was insignificant with the organophosphates tested since the day of treatment 
The damage caused by $S$. zeamais on stored corn was approximately 5 times greater than that caused by $R$. dominica, with 16 and $3 \%$ of damage, respectively. According to legislation, the maximum detectable limit of residues and the safety interval for stored corn are: $1 \mathrm{mg} / \mathrm{kg}$ and 30 days for deltamethrin, $8 \mathrm{mg} / \mathrm{kg}$ and 60 days for malathion and $10 \mathrm{mg} / \mathrm{kg}$ and 30 days for pirimiphos-methyl. Based on the results obtained herein, it is necessary a better understanding and further evaluation of the legislation regarding the above-mentioned toxicological parameters. For example, the recommended use-rate of deltamethrin is equal to the allowed maximum limit of residues, the safety interval for malathion is approximately 2.5 times greater than that established by law, and the maximum limit of pirimiphos-methyl residues is superior to the recommended rate for stored grains. 


\section{INTRODUÇÃO}

O desenvolvimento da agricultura, a ampliação das fronteiras agrícolas e, principalmente, a demanda dos mercados de produtos em quantidade e qualidade, tem exigido o uso de defensivos agrícolas para a garantia de sua produtividade.

$\mathrm{Na}$ luta da humanidade contra os inimigos das lavouras, tem-se adotado vários métodos que, isoladamente ou associados, na forma de controle integrado, conseguem reduzir a baixos níveis os prejuízos causados por pragas, doenças e plantas daninhas.

O meio criado pelos grandes depósitos de grãos, farelos, farinhas, rações, frutas secas, queijos e outros produtos, oferecem muitas vantagens às numerosas espécies vegetais e animais que os habitam, principalmente pela grande fonte de alimentação e proteção contra extremos de temperatura, permitindo a alguns destes organismos alimentarem-se e reproduzirem-se durante todo o ano (FLECHTMANN, 1986). Assim, há necessidade de dar atenção a essas pragas, pois pouco adiantariam todos os cuidados e despesas para seu controle no campo, se a produção for atacada e destruída nos depósitos . 
De acordo com os dados da FAO (GALLO et al., 1988), estima-se em $10 \%$ as perdas na produção mundial de cereais armazenados, que segundo a FAO (1993), foi de 1.960 .569 .000 toneladas em 1992, sendo o milho representado por aproximadamente $27 \%$ dessa produção. No Brasil, as perdas atingem níveis de $20 \%$, para uma produção de cereais de 44.165 .000 toneladas na mesma safra, das quais o milho, contribuiu com aproximadamente $70 \%$ deste volume. Estas altas porcentagens de perdas devem-se principalmente às condições de armazenamento no meio rural serem muito precárias.

Entre os organismos daninhos aos produtos armazenados, os insetos se classificam como os de maior importância não só pela diversidade de espécies presentes, como também pelo nível de dano que causam. Dentre eles, assume importância crescente o besourinho Rhyzopertha dominica, Fabr., 1792.

Em face do problema causado pelos insetos nos armazéns, tem-se usado principalmente substâncias químicas para controlá-los e para a preservação das colheitas; por outro lado, podem ocorrer persistência destes inseticidas na forma de resíduos tóxicos nos grãos tratados, cujo consumo por parte do homem ou animal, mesmo em doses subletais, representa risco potencial à saúde dos consumidores (RIGITANO, 1979).

Os limites máximos de resíduos (tolerância) e intervalo de segurança estabelecidos no Brasil, para resíduos de pesticidas em grãos armazenados, são na maioria das vezes baseados em trabalhos estrangeiros.

Nas condições brasileiras, as variações climáticas, diferenças varietais e tipos de formulações empregadas, além das próprias características de armazenamento, 
influenciam o comportamento residual dos inseticidas empregados no controle das pragas dos armazéns. Assim sendo, é necessário desenvolver pesquisa nesta área nas condições brasileiras.

Deste modo, foi conduzido o presente trabalho, cujos objetivos foram:

a) Estudar a persistência dos resíduos de deltametrina, malation e pirimifós-metil em grãos de milho armazenados;

b) Estabelecer as curvas de degradação destes defensivos agrícolas nos grãos;

c) Estudar a ação destes defensivos agrícolas sobre os adultos de $R$.

dominica,

d) Correlacionar os níveis residuais encontrados com os limites máximos de resíduos (tolerâncias) e os intervalos de segurança (carência) estabelecidos pela legislação. 


\section{REVISÃO DA LITERATURA}

2.1. Comportamento de resíduos de inseticidas e sua legislação em grãos anmazenados

A recomendação de um defensivo agrícola, visando o controle de pragas, doenças, plantas daninhas, etc., deve ser feita levando-se em conta a relação custo/beneficio, de modo que esses produtos químicos sejam aplicados com toda segurança possível aos aplicadores e não deixem resíduos prejudiciais nos alimentos, acima das tolerâncias legalmente aceitas.

Segundo GIANNOTTI (1971), após a aplicação de um defensivo em plantas, frutos, raízes, grãos e produtos armazenados, a camada que recobre as partes tratadas deve ser considerada como depósito do pesticida. Ao sofrer a ação dos fatores ambientais, esta camada deve então ser denominada de resíduo; assim, GALLO et al. (1988) citam que um "depósito" torna-se um "resíduo", tão logo ele seja afetado por lavagem, conversões metabólicas ou outros processos de alteração que causem diminuição na quantidade aplicada. 
No estudo de comportamento de defensivos agrícolas, uma das determinações importantes é o valor da "meia-vida", definido por Gunther \& Blinn (1955)', citado por PIZANO (1988), como sendo o tempo necessário para que a metade de uma dada quantidade de material reaja ou dissipe. Segundo GUNTHER (1969), para um determinado pesticida e substrato, o valor da meia-vida é constante, sendo este parâmetro utilizado em comparações de persistência (longevidade) entre pesticidas.

DESMARCHELIER (1977) relata que as condições de temperatura de armazenamento e a porcentagem de umidade de grãos de trigo influenciaram na persistência dos resíduos de malation, enquanto que para pirimifós-metil estas mesmas condições ambientais não afetaram sua degradação.

$\mathrm{Na}$ Tabela 1, observa-se que além do inseticida considerado, também o tipo de grão armazenado influencia a duração do período de meia-vida de degradação dos pesticidas (La HUE, 1975 e KADOUM \& La HUE, 1979). O grau de umidade dos grãos também atua diretamente na duração do referido período (KADOUM \& La HUE, 1979 e NOBLE et al., 1982), o mesmo ocorrendo com a dosagem inicial aplicada (McGAUGEY, 1971; La HUE, 1975 e COGBURN, 1976).

A tolerância ou limite máximo de resíduos é a quantidade máxima de resíduos de um pesticida tolerada em um alimento, como decorrência de sua aplicação adequada, numa fase específica desde sua produção até o consumo, expressa em partes (em peso) do pesticida e/ou seus metabólitos por um milhão de partes (em peso) do alimento (ppm) (GELMINI, 1991).

\footnotetext{
1 GUNTHER, F.A. \& BLINN, R.C. Analysis of insecticides and acaricides. New York, Interscience, 1955. 696p.
} 
Tabela 1. Valores de meia-vida de persistência de alguns defensivos agrícolas em grãos armazenados.

\begin{tabular}{|c|c|c|c|c|}
\hline $\begin{array}{l}\text { Defensivo } \\
\text { agrícola }\end{array}$ & $\begin{array}{c}\text { Dosagem } \\
\text { (ppm) }\end{array}$ & $\begin{array}{c}\text { Produto } \\
\text { armazenado }\end{array}$ & $\begin{array}{l}\text { Meia-vida } \\
\text { (dias) }\end{array}$ & $\begin{array}{l}\text { Referência } \\
\text { Bibliográfica }\end{array}$ \\
\hline Malation & 10 & trigo & 66 & La HUE (1975) \\
\hline Pirimifós-metil & 5 & trigo & 26 & La HUE (1975) \\
\hline Pirimifós-metil & 10 & trigo & 78 & La HUE (1975) \\
\hline Pirimifós-metil & 20 & trigo & 90 & La HUE (1975) \\
\hline Malation & 10 & milho & 74 & La HUE (1975) \\
\hline Pirimifós-metil & 5 & milho & 77 & La HUE (1975) \\
\hline Pirimifós-metil & 10 & milho & 78 & La HUE (1975) \\
\hline Pirimifós-metil & 20 & milho & 90 & La HUE (1975) \\
\hline Malation & 10 & trigo & $120(12 \% U)$ & KADOUM \& La HUE (1979) \\
\hline Malation & 10 & milho & $180(12 \% U)$ & KADOUM \& La HUE (1979) \\
\hline Malation & 14 & arroz (casca) & 30 & McGAUGEY (1971) \\
\hline Malation & 21 & arroz (casca) & 25 & McGAUGEY (1971) \\
\hline Malation & 28 & arroz (casca) & 25 & McGAUGEY (1971) \\
\hline Malation & 14 & arroz (casca) & 30 & COGBURN (1976) \\
\hline Pirimifós-metil & 5 & arroz (casca) & 128 & COGBURN (1976) \\
\hline Pirimifós-metil & 10 & arroz (casca) & 140 & COGBURN (1976) \\
\hline Pirimifós-metil & 15 & arroz (casca) & 158 & COGBURN (1976) \\
\hline Deltametrina & - & trigo & $630(15 \% U)$ & $\begin{array}{l}\text { SODERLAND \& CASIDA } \\
(1977)\end{array}$ \\
\hline Deltametrina & 2 & trigo & $798(12 \% U)$ & NOBLE et al. (1982) \\
\hline Deltametrina & 2 & trigo & $245(15 \% U)$ & NOBLE et al. (1982) \\
\hline
\end{tabular}


A Tabela 2 apresenta os limites máximos de resíduos e ingestão diária aceitável (IDA) de alguns inseticidas utilizados para controle de pragas em produtos armazenados. Nesta, observa-se que estes parâmetros toxicológicos são variáveis de acordo com o inseticida, o produto armazenado e a referência bibliográfica.

Tabela 2. Limites máximos de resíduos e ingestão diária aceitável (IDA) de defensivos agrícolas em produtos armazenados.

\begin{tabular}{|c|c|c|c|c|}
\hline $\begin{array}{l}\text { Defensivo } \\
\text { agrícola }\end{array}$ & $\begin{array}{l}\text { Produto } \\
\text { armazenado }\end{array}$ & $\begin{array}{l}\text { Tolerância } \\
\text { (ppm) }\end{array}$ & $\begin{array}{c}\text { IDA } \\
(\mathrm{mg} / \mathrm{kg} / \mathrm{PV})\end{array}$ & $\begin{array}{l}\text { Referência } \\
\text { Bibliográfica }\end{array}$ \\
\hline & soja & 0,5 & - & TOMIZAWA (1977) \\
\hline & $\begin{array}{l}\text { aveia/cereais } \\
\text { cereais e }\end{array}$ & 0,5 & - & JPI (1987) \\
\hline \multirow[t]{6}{*}{ Malation } & $\begin{array}{l}\text { subprodutos } \\
\text { feijões e }\end{array}$ & 8,0 & 0,02 & FAO/OMS (1967) \\
\hline & lentilhas & 8,0 & 0,02 & FAO/WHO (1974) \\
\hline & arroz & 8,0 & - & COGBURN et al. (1990) \\
\hline & cereais & 8,0 & - & GELMINI \& NOVO (1987) \\
\hline & arroz & 0,5 & 0,005 & JPI (1987) \\
\hline & $\begin{array}{l}\text { trigo, centeio, } \\
\text { arroz }\end{array}$ & 10 & 0,005 & FAO/WHO (1975) \\
\hline \multirow[t]{3}{*}{ Pirimifós-metil } & $\begin{array}{l}\text { cevada, milho, } \\
\text { aveia }\end{array}$ & 7 & - & FAO/WHO (1975) \\
\hline & sorgo & 10 & - & BENGSTON et al. (1983) \\
\hline & cereais & 10 & - & GELMINI \& NOVO (1987) \\
\hline Deltametrina & cereais & 1 & - & GELMINI \& NOVO (1987) \\
\hline
\end{tabular}


De acordo com Harvey $(1961)^{2}$, Jewel $(1961)^{3}$ e Larrick (1957, 1961a,b e 1962), citados por ROWLANDS (1967), a tolerância de resíduos de malation em cereais é de 8 ppm no Reino Unido, Canadá e Estados Unidos, e 3 ppm na Índia. Em alimentos em geral, na Austrália, Estados Unidos e União Soviétiva é 8 ppm, sendo 7 ppm na Áustria.

Segundo a Portaria n 10 de 08 de março de 1985 da Secretaria Nacional de Vigilância Sanitária (SNVS) do Ministério da Saúde, os limites máximos de resíduos no Brasil de deltametrina, malation e pirimifós-metil em grãos armazenados são $1 ; 8$ e 10 ppm, respectivamente.

Por intervalo de segurança ou período de carência entende-se "o intervalo, expresso em dias, entre a última aplicação do pesticida e a colheita e comercialização do produto colhido, abate ou ordenha do animal, conforme o caso, afim de que os resíduos estejam de acordo com os limites máximos de resíduos permitidos" (ASTOLFI \& LANDONI, 1984 e GELMINI, 1991).

A ingestão diária aceitável (IDA) "é a quantidade máxima do ingrediente ativo e/ou seus metabólitos que, ingerida diariamente durante toda a vida, parece não oferecer riscos apreciáveis à saúde, à luz dos conhecimentos atuais, e é expressa em mg do pesticida por kg de peso corpóreo (mg/kg/dia)" (ASTOLFI \& LANDONI, 1984).

\footnotetext{
${ }^{2}$ HARVEY, J.L. Tolerances and exeptions from tolerances for pesticide chemicals in on raw arailual commodities. Chemical Abstracts, 55: $10741 \mathrm{a}, 1961$.

${ }^{3}$ JEWEL, W.R. Food additive control in Austrália. FAO. Food additive control, Ser. n. 4, 1961.

- LARRICK, G.R. Tolerances and exceptions for tolerances for pesticides chemicals in or on raw agricultural commodities. Chemical Abstmets, 52: 22916, 1957. Ibid, 55: 10470i, 1961a; Mid, 55: 23857f; 196Ib; Ibid, 57: 17144h, 1962.
} 


\subsubsection{Resíduos de inseticidas em grãos ammazenados}

$\mathrm{Na}$ utilização de produtos químicos em mistura com as massas de grãos, visando sua proteção contra o ataque de pragas, deve-se considerar as normas relacionadas com os resíduos, que definem tolerâncias variáveis para consumo, de acordo com o inseticida empregado e o tipo de grão armazenado.

Segundo McGAUGEY (1971), de um depósito inicial de 20 ppm de malation em arroz em casca, resíduos inferiores a 8 ppm foram encontrados 3 meses após a aplicação. Nos grãos benefíciados, o nível residual encontrado foi de $0,32 \mathrm{ppm}$.

De acordo com La HUE (1975), depósitos iniciais de pirimifós-metil de 5, 10 e 20 ppm em grãos de milho, resultaram níveis residuais de 6,9 e 2,1 ppm, 24 horas e 3 meses após o tratamento, respectivamente, para a dosagem de 5 ppm; 8,0 e 4,7 ppm para a dosagem de 10 ppm e 10,8 e 10,0 ppm para a dosagem de 20 ppm, para os mesmos períodos de armazenamento. De uma dosagem padrão de $10 \mathrm{ppm}$ de malation em grãos de trigo, obteve-se resíduos de 9,0 e 4,0 ppm, 24 horas e 3 meses após a aplicação, respectivamente, enquanto que em grãos de milho, resultaram níveis de 7,8 e 4,2 ppm nas mesmas datas de análise.

De acordo com Bullock (1973) ${ }^{5}$, citado por WORLD HEALTH ORGANIZATION (1975), grãos de trigo tratados com 4 ppm de pirimifós-metil, apresentaram, após 3 meses da aplicação, resíduos de: 1,87;1,73;1,99;2,17 e 2,04 ppm, quando foram extraidos pelos seguintes solventes: diclorometano, acetona, $20 \%$ de acetona

\footnotetext{
'BULLOCK, D.J.W. Pirimiphos methyl: residues in stored grain. Plant Protection Ltda. Report $n^{\circ}$. AR 2472 AR (Umpublished), 1973.
} 
quando foram extraídos pelos seguintes solventes: diclorometano, acetona, $20 \%$ de acetona em hexano, metanol e metanol (1 hora de refluxo). Em grãos de cevada, para a mesma dosagem aplicada, resultaram resíduos de 1,$53 ; 1,71 ; 1,47 ; 1,84$ e 1,70 ppm; e em grãos de arroz, 1,$41 ; 1,95 ; 1,84 ; 1,99$ e $1,03 \mathrm{ppm}$, foram encontrados para a mesma dosagem aplicada de pirimifós-metil e à mesma sequência de solventes.

KADOUM \& La HUE (1979) estudaram o efeito da umidade em grãos de trigo e milho na degradação de 10 ppm de malation. Após 24 horas da aplicação, 9,$7 ; 9,2 ; 7,3$ e 5,7 ppm foram recuperados para os níveis de $10,12,14$ e $16 \%$ de umidade em grãos de milho; em grãos de trigo os níveis residuais foram: 9,6;9,6;7,7 e 6,4 ppm, respectivamente, para os mesmos graus de umidade. Aos 6 meses após o tratamento, níveis de 5,$2 ; 5,0 ; 1,8$ e $1,2 \mathrm{ppm}$ foram encontrados para $10,12,14$ e $16 \%$ de umidade nos grãos de milho e 5,$6 ; 4,1 ; 1,8$ e 1,6 ppm para os mesmos níveis de umidade em grãos de trigo. Aos 12 meses os niveis residuais foram de 3,$4 ; 2,4 ; 0,8$ e 0,5 ppm para grãos de milho e 4,$1 ; 2,1 ; 0,7$ e $0,3 \mathrm{ppm}$ em grãos de trigo, respectivamente, para as porcentagens de umidade já referidas. Os autores ainda relataram que a degradação de malation foi mais rápida nos grãos com maior grau de umidade e com o aumento no tempo de armazenamento.

MENSAH et al. (1979) aplicaram 8 e 12 ppm de malation em grãos de trigo com 12 e 16\% de umidade. Após 1, 3 e 6 meses da aplicação, resíduos de 6,24; 3,19 e $2,62 \mathrm{ppm}$ foram encontrados para a menor dosagem e resíduos de 10,$06 ; 6,59$ e 4,52 ppm para a maior, em grãos que continham $12 \%$ de umidade. Em relação aos grãos com $16 \%$ de umidade, resíduos de 4,97; 1,79 e $1,19 \mathrm{ppm}$ foram encontrados para o tratamento 
com 8 ppm e 8,50; 4,57 e 1,45 ppm para o tratamento com $12 \mathrm{ppm}$, nos mesmos períodos decorridos da aplicação. Os mesmos autores relatam que da aplicação de 4 e 6 ppm de pirimifós-metil em grãos de trigo, com 12 e $16 \%$ de umidade, resíduos de 3,29; 2,98 e 2,54 ppm foram obtidos para a menor dosagem e 4,93; 4,54 e 3,66 ppm para a maior, em grãos com $12 \%$ de umidade, 1,3 e 6 meses após o tratamento, respectivamente. Para grãos tratados com $16 \%$ de umidade, resíduos de 3,24; 3,04 e $2,26 \mathrm{ppm}$ foram obtidos para a menor dosagem e 4,$92 ; 4,44$ e 3,86 ppm para a maior, nos mesmos periodos após o tratamento.

A recuperação residual de 5,1 e 3,1 ppm em grãos de trigo, 1 dia e 39 semanas após a aplicação de 6 ppm de pirimifós-metil e foi obtida por DAVIES \& DESMARCHELIER (1981).

HARGREAVES et al. (1982) trataram grãos de trigo com $12 \%$ de umidade com dosagens de deltametrina que variaram de 0,125 a $16 \mathrm{ppm}$ e citam que a dosagem do piretróide recomendada na Austrália para tratamento de grãos é $1 \mathrm{ppm}$. A recuperação residual das dosagens de 0,5 e $1,0 \mathrm{ppm}$, aos zero dia, 8 e 15 meses da aplicação, foi 0,45 e $0,84 \mathrm{ppm} ; 0,43$ e $0,92 \mathrm{ppm}$ e 0,47 e $0,94 \mathrm{ppm}$, respectivamente.

NOBLE et al. (1982) aplicaram os seguintes inseticidas piretróides e dosagens em grãos de trigo: permetrina (1 ppm), fenotrina ( $2 \mathrm{ppm})$, fenvalerato (1 ppm) e deltametrina ( $2 \mathrm{ppm})$. Os grãos foram armazenados a $25^{\circ} \mathrm{C}$ de temperatura e $12 \%$ de umidade e $35^{\circ} \mathrm{C}$ e $15 \%$. As análises residuais feitas aos zero dia, 13, 26, 39 e 52 semanas após o tratamento revelaram, em relação a deltametrina, resíduos de 2,07 e 1,95 ppm; 1,91 e $1,74 \mathrm{ppm} ; 1,83$ e $1,34 \mathrm{ppm} ; 1,66$ e $1,25 \mathrm{ppm}$ e 1,46 e $0,66 \mathrm{ppm}$, respectivamente, para as duas condições de armazenamento. 
De acordo com BITRAN et al. (1983), na utilização de deltametrina em misturas com grãos, deve-se considerar as normas relacionadas com resíduos, que estabelecem uma tolerância de $1 \mathrm{ppm}$ em grãos de milho e trigo armazenados. As normas também consideram uma tolerância de apenas $0,005 \mathrm{ppm}$ para milho armazenado a granel e em espiga com palha, havendo discrepâncias e dúvidas em relação a Portaria nº. 13/SNVS de 14/03/1983. A utilização de deltametrina no tratamento de milho a granel, com dosagens de 0,5 e 1,0 ppm, certamente manteria níveis residuais superiores a 0,005 ppm, mesmo após 6 meses de armazenamento, mostrando que é necessário uma melhor definição dos resíduos deste inseticida para o consumo dos grãos tratados.

KIRKPATRICK et al. (1983) aplicaram 11 e $10 \mathrm{ppm}$ de malation e fenitrotion, respectivamente, em grãos de milho. As amostragens para análise de resíduos, feitas aos $0,1,3,6,9$ e 12 meses revelaram níveis residuais de 12,$1 ; 9,2 ; 7,2 ; 6,1 ; 2,8$ e $2,7 \mathrm{ppm}$ de malation, respectivamente. Os níveis residuais de: 12,$6 ; 12,4 ; 11,2 ; 7,5 ; 3,8$ e $3,9 \mathrm{ppm}$ de fenitrotion foram detectados nas mesmas datas de análise.

Para o controle de pragas resistentes a malation de grãos de sorgo armazenados, BENGSTON et al. (1984) utilizaram deltametrina + butóxido de piperonila (2 e $8 \mathrm{ppm})$ e pirimifós-metil + permetrina + butóxido de piperonila $(6 ; 1$ e 8 ppm), respectivamente. Os resíduos encontrados nos grãos amostrados 0,17 e 26 semanas após o tratamento foram 1,$8 ; 1,5$ e $1,0 \mathrm{ppm}$ de deltametrina, respectivamente, enquanto que estes apresentaram níveis de 6,$5 ; 4,2$ e 3,5 ppm de pirimifós-metil nos mesmos períodos.

SOWUNMI \& FETUGA (1985) trataram grãos de milho com 20 ppm de pirimifós-metil que foram armazenados a granel, em silos. Os autores relataram que $70 \%$ 
do depósito inicial do inseticida foi degradado em 5 meses de armazenamento. Por outro lado, grãos de milho tratados com 10 ppm do mesmo inseticida e armazenados em sacos de juta e polietileno, tiveram meia-vida de degradação dos resíduos somente 12 meses após a aplicação.

COGBURN et al. (1990) obtiveram resíduos de 7,48 e 8,22 ppm, 1 e 12 semanas, respectivamente, após o tratamento de grãos de arroz com 14 ppm de malation. Nas mesmas datas de análise, níveis residuais de 4,45 e 2,3 ppm foram encontrados, resultado do tratamento com pirimifós-metil a 6 ppm em grãos de arroz.

A recomendação para o tratamento de grãos de trigo e cevada com pirimifós-metil, segundo Le PATOUREL (1992) é de 4 ppm no Reino Unido. O autor aplicou dosagens calculadas de 3,9 e 3,7 ppm do inseticida nos grãos, respectivamente, obtendo em trigo, no período de 0 a 240 dias, variação residual de 1,44 a 1,33 ppm. Em grãos de cevada, no período de 0 a 210 dias, obteve-se a variação de 4,03 a 3,62 ppm. Concluiu-se que não houve variação residual de pirimifós-metil durante os períodos estudados, mas que houve grande variação nos pontos amostrados, revelando grande irregularidade no método de aplicação.

\subsection{Características da deltametrina}

Segundo GALLO et al. (1988), a deltametrina é um composto químico piretróide sintético com propriedades inseticidas, agindo por contato e ingestão. 
g.i.a.ha. É usado na agricultura, pecuária e saúde pública, sendo constituído por apenas um isômetro, o D-cis.

De acordo com CAVERO (1982), deltametrina apresenta o nome químico(S)-alfa-ciano-m-fenoxi-benzil (1R-3R)-cis-3-(2,2-dibromo vinil)-2,2-dimetilciclopropano carboxilato, fórmula bruta, $\mathrm{C}_{22} \mathrm{H}_{19} \mathrm{Br}_{2} \mathrm{No}_{3}$ e fórmula estrutural plana (Figura 1).

Figura 1. Fórmula estrutural plana de deltametrina.

A dose letal $50\left(\mathrm{DL}_{50}\right)$ aguda oral para ratos é de $7526 \mathrm{mg} / \mathrm{kg}$ e a dérmica para coelhos é de 1782-2000 mg/kg (CAVERO, 1982).

Segundo GELMINI (1991) é registrado para aplicação nas partes aéreas das culturas de algodão, alho, amendoim, ameixa, arroz, batata, berinjela, brócolis, cebola, melão, melancia, pêssego, pepino, pimentão, plantas ornamentais, repolho, seringueira, sorgo, soja, trigo, tomate, vagem e produtos armazenados a granel ou ensacados de arroz, café, feijão, milho, trigo, cevada e centeio

GALLO et al. (1988), relatam que para o controle de pragas dos 
grãos armazenados, a dosagem do piretróide varia de 0,1 a 1,0 ppm e tem sua atividade duplicada quando sinergizado com butóxido de piperonila.

A metodologia empregada para análise de resíduos de deltametrina em grãos armazenados, por cromatografia a gás foi estudada por HARGREAVES et al. (1974); MESTRES et al. (1978, 1979); NOBLE et al. (1982) e BENGSTON et al. (1983). Segundo GELMINI \& NOVO (1987), a tolerância residual de deltametrina para os grãos armazenados é de $1 \mathrm{ppm}$, com períodos de carência de 30 dias para produtos a granel, 7 dias para milho em palha e 15 dias para produtos ensacados (Portaria $n^{\circ} .10$ de 08 de março de 1985 do Ministério da Saúde).

\subsection{Características do malation}

Segundo GALLO et al. (1988), o malation é um composto químico organofosforado, com propriedades inseticidas, acaricidas, com ação de contato, ingestão, fumigação e profundidade. É conhecido quimicamente por 0,0-dimetil ditiofosfato dietilmercaptosuccinato (CAVERO, 1982). A $\mathrm{DL}_{50}$ oral para ratos é $1375 \mathrm{mg} / \mathrm{kg}$ e a $\mathrm{DL}_{50}$ dérmica para coelho é $4100 \mathrm{mg} / \mathrm{kg}$ (NAKANO et al., 1977).

Apresenta fórmula bruta $\mathrm{C}_{10} \mathrm{H}_{19} \mathrm{O}_{6} \mathrm{PS}_{2}$ e a fórmula estrutural plana se encontra na Figura 2 
Figura 2. Fórmula estrutural plana de malation.

Malation é registrado para controle de ácaros, cochonilhas sem carapaça, cigarrinhas, lagartas, gorgulhos, moscas das frutas, brocas, percevejos, pulgões, moscas, traças, piolhos, trips, besouros, etc. nas diversas formulações e nomes comerciais (CAVERO et al., 1976).

De acordo com LIMA \& RACCA FILHO (1987) é registrado para algodão, ameixa, amendoim, berinjela, brócolis, cereais, cereja, chicória, citros, couves, cucurbitáceas, espinafre, feijão, forragens, frutas secas, frutos, hortaliças, leguminosas frescas, maçã, morango, nabo, nozes, pastagens, pera, pêssego, pimentão, raízes, repolho, salsão, soja, tomate, tubérculos. Também é registrada para grãos armazenados e uso doméstico.

GELMINI (1991) relata que a tolerância de malation para grãos armazenados é de 8 ppm e período de carência de 60 dias. Apresenta uma ingestão diária aceitável (IDA) de 0,02 mg/kg de peso vivo (CAVERO, 1982). GELMINI (1991) cita que a Portaria $n^{\circ}$. 26 de 29 de julho de 1983 da SDSV proibe o uso de malation nas formulações 2 e $4 \%$ em pó para o tratamento de milho em espiga, para o controle de pragas, devido à sua comprovada ineficiência. 
formulações 2 e $4 \%$ em pó para o tratamento de milho em espiga, para o controle de pragas, devido à sua comprovada ineficiência.

Alguns pesquisadores tais como KIRKPATRICK et al. (1982) e MUCCIO et al. (1990) estudaram metodologias de análise de malation em grãos armazenados por cromatografia a gás.

\subsection{Características do pirimifós-metil}

Segundo GELMINI (1991) o pirimifós-metil é um composto químico com propriedade inseticida e ação de contato e fumigação; nome comercial Actellic e nome químico 0-2-dimetilanino-6-metil pirimidin-4il-0,0-dimetil-fosforotionato.

A fórmula bruta é $\mathrm{C}_{11} \mathrm{H}_{20} \mathrm{~N}_{3} \mathrm{O}_{3} \mathrm{PS}$ e a fórmula estrutural plana se encontra na Figura 3.

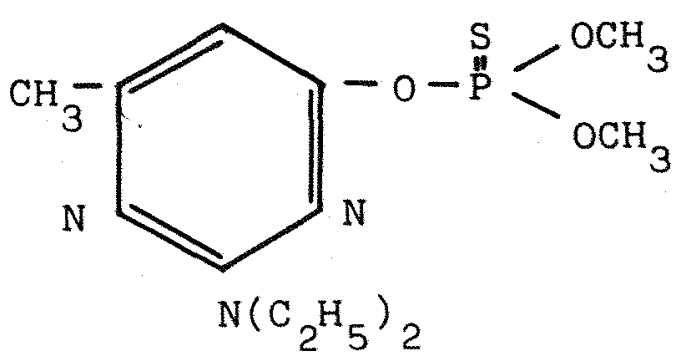

Figura 3. Fórmula estrutural plana de pirimifós-metil 
Pirimifós-metil apresenta $\mathrm{DL}_{50}$ oral de $1415 \mathrm{mg} / \mathrm{kg}$ e $\mathrm{DL}_{50}$ dérmica de $>2000 \mathrm{mg} / \mathrm{kg}$ para coelhos (CAVERO, 1982). É registrado para aplicação na parte aérea das culturas de alface, citros, couve, feijão, feijão vagem e no armazenamento de grãos de arroz, cevada, milho e trigo, para controle de pragas dos grãos armazenados, besouros, cochonilhas, trips, curuquerê e carunchos. Em grãos armazenados, recomenda-se aplicar 8 a 16 mililitros de Actellic $500 \mathrm{CE}$ para uma tonelada de grãos, visando o controle de carunchos e traças (GELMINI \& NOVO, 1987).

A formulação de Actellic $2 \%$ em pó é empregada na dosagem de $3 \mathrm{~g}$ para cada $\mathrm{m}^{2}$ de área ensacada, a cada 4 meses, na prevenção do ataque de pragas nas sacarias, enquanto que para produtos a granel, utiliza-se $20 \mathrm{~g}$ do pó por $\mathrm{m}^{2}$ de superfície de grãos. A formulação $500 \mathrm{CE}$ é empregada na pulverização de sacarias, com $5 \mathrm{ml}$ do produto para $50 \mathrm{ml}$ de água por $\mathrm{m}^{2}$ de sacarias, enquanto que para produtos a granel, recomenda-se a concentração de 4 ppm (CAVERO, 1982).

A metodologia empregada para análise de resíduos de pirimifós-metil em grãos armazenados por cromatografia a gás foi estudada por LEVI \& NOWICKI (1974); DESMARCHELIER et al. (1977) e WHITE \& ABRANSON (1984).

A tolerância ou limite máximo de resíduos, assim como o período de carência de pirimifós-metil em grãos armazenados foram estabelecidos pela Portaria $\mathrm{n}^{\circ}$. 10/SNVS de 08 de março de 1985 do M.S., em 10 ppm e 30 dias, respectivamente (GELMINI \& NOVO, 1987). 


\subsection{Controle de pragas dos gräos annazenados}

A tecnologia utilizada para a preservação dos grãos da deterioração nos armazéns, encontra nas pragas um dos principais inimigos a serem combatidos, para a manutenção da qualidade destes produtos. Em face disto, inúmeras pesquisas com inseticidas tem sido desenvolvidas mundialmente neste campo.

La HUE (1975), com a aplicação de pirimifós-metil nas dosagens de 5, 10 e 20 ppm em grãos de trigo e milho, relata que controlou totalmente os adultos de Rhyzopertha dominica, infestados nos grãos 24 horas e um mês após o tratamento. A proteção dos grãos se estendeu por 3 meses, a despeito do nascimento da geração $F_{1}$ nos tratamentos $5 \mathrm{ppm}$ em milho e 5 e $10 \mathrm{ppm}$ em trigo.

Segundo COGBURN (1976) a dosagem de $14 \mathrm{ppm}$ de malation controlou $R$. dominica em $100 ; 97,1 ; 88,3$ e $48,8 \%$ nos meses $1,2,3$ e $6^{\circ}$, respectivamente, após o tratamento de grãos de arroz. Pirimifós-metil controlou o inseto em 100 e 95,1\%; 34,3 e 88,$62 ; 48,8$ e $90,4 \%$ e 21,2 e $56,7 \%$ nas concentrações de 10 e 15 ppm, respectivamente 1, 2, 3 e 6 meses após o tratamento. A dosagem de 5 ppm foi inefíciente em todas as épocas de avaliação.

De acordo com DAVIES \& DESMARCHELIER (1981), a aplicação de $5,1 \mathrm{mg} / \mathrm{kg}$ de pirimifós-metil em grãos de trigo controlou eficientemente Sitophilus granarius (Col., Curculionidae) e Tribolium confusum (Col., Tenebrionidae) por 39 semanas, mas foi ineficiente contra a raça CRD 118 de $R$. dominica, resistente a malation. A mistura de $1,8 \mathrm{mg} / \mathrm{kg}$ de pirimifós-metil com $5,7 \mathrm{mg} / \mathrm{kg}$ de carbaril controlou $S$. granarius e $R$. dominica, mas não $T$. confusum. A combinação de $4,2 \mathrm{mg} / \mathrm{kg}$ de pirimifós-metil com 
$3,4 \mathrm{mg} / \mathrm{kg}$ de carbaril foi mais eficiente contra $T$. confusum do que contra $R$. dominica. Os autores recomendam a adição de 5 a $6 \mathrm{mg} / \mathrm{kg}$ de carbaril a 4 a $5 \mathrm{mg} / \mathrm{kg}$ de pirimifós metil, quando $R$. dominica é problema e longo período de armazenamento é requerido.

BENGSTON et al. (1983) relataram que deltametrina $(2 \mathrm{ppm})+$ butóxido de piperonila (BP) (8 ppm); fenitrotion (12 ppm) + fenvalerato (1 ppm) + BP (8 ppm); fenitrotion (12 ppm) + fenotrina (2 ppm) + BP (8 ppm) e pirimifós-metil (4 ppm) + permetrina $(1 \mathrm{ppm})+$ BP $(8 \mathrm{ppm})$ controlaram raças comuns de campo de Sitophilus oryzae (Col., Curculionidae) e $R$. dominica em grãos de trigo armazenados por mais de 9 meses.

A toxicidade de 26 inseticidas foi testada em laboratório por HSIEH et al. (1983) contra $S$. zeamais e $R$. dominica em tratamento de grãos de milho. Todos os inseticidas foram mais tóxicos a $S$. zeamais do que a $R$. dominica, com exceção a azinfósetil, clorfenvinfós, carbaril, metomil, deltametrina, fenvalerato e permetrina. Deltametrina foi o mais tóxico a $R$. dominica com $\mathrm{CL}_{50}$ de $0,07 \mathrm{ppm}$, enquanto que triclorfon foi o menos tóxico com $\mathrm{CL}_{50}$ de 1505 ppm.

KIRKPATRICK et al. (1983) citam que fenitrotion $(6,10$, e 15 ppm) foi mais eficiente que malation (11 ppm) no controle de Tenebroides mauritanicus (L.) (Col-Ostomidae), R. dominica, S. zeamais (Mots) (Col.-Curculionidae), Cathartus quadricolis (Gue-Men) (Col.-Cucujidae), Ephestiacautela(W.) e Plodia interpunctella(Lep., Pyralidae) em grãos de milho armazenados por cerca de 1 ano

REZENDE et al. (1984) trataram 10.000 toneladas de grãos de trigo em armazém da CEAGESP em Palmital-SP, com 0,35 ppm de deltametrina e infestaram amostras dos grãos tratados com Sitophilus spp., R. dominica e Tribolium spp., que foram 
acondicionadas em gaiolas. A mortalidade foi avaliada mensalmente até 180 dias após a aplicação, quando avaliaram controle de $80 \%$ para Sitophilus spp. e $95 \%$ de $R$. dominica e Tribolium spp.

A mistura de deltametrina com butóxido de piperonila na dosagem de 0,5 ppm, segundo KORUNIC \& HAMEL-KOREN (1985), foi altamente eficiente contra os gorgulhos S. oryzae, S. granarius e $R$. dominica por 168 dias, excetuando-se para $T$. confusum. Pirimifós-metil a 4 ppm, protegeu os grãos armazenados no mesmo período contra os gorgulhos, sendo ineficiente contra $T$. confusum. Em relação a $R$. dominica foi efíciente até 28 dias, com decréscimo da eficiência aos 56 dias e inativo aos 84 dias.

RANZAN \& CHAHAL (1987) estudaram a ação de cipermetrina, permetrina, deltametrina e fenvalerato nas dosagens de 2,4 e 8 ppm em grãos de trigo para controle de $R$. dominica. Aos dois meses após a aplicação, os inseticidas proveram controle de 82 a $100 \%$ da praga.

A eficiência do tratamento de sacos de juta e sementes de trigo com malation, pirimifós-metil e deltametrina contra $R$. dominica foi estudada por BARETH \& GUPTA (1989). Durante 15 meses os autores observaram um mínimo de dano nos sacos e sementes tratadas com 0,01 e $0,75 \mathrm{ppm}$ de deltametrina, respectivamente.

SANSON \& PARKER (1989) relatam que a ordem de eficiência de controle de $R$. dominica em milho armazenado foi: deltametrina $>$ fenvalerato $>$ permetrina $=$ cipermetrina $>$ D-fenotrina. A praga foi controlada com $0,04 \mathrm{ppm}$ de deltametrina, 0,25 ppm de fenvalerato e 0,5 a 1,0 ppm de permetrina por 9 meses. 
SKARIA et al. (1989) relatam que as concentrações de 0,75 e 1,0 ppm de deltametrina, aplicadas em grãos de arroz infestados com $R$. dominica, permitiram um aumento populacional superior à testemunha.

As dosagens de 0,$35 ; 0,75$ e 1,0 ppm de deltametrina controlaram $R$. dominica até 375 dias após a aplicação em grãos de trigo, segundo BENDECK et al. (1991). Malation, 20 ppm, controlou o besourinho até 75 dias da aplicação com 90,6\% de mortalidade, mostrando-se ineficiente após este período.

O controle das duas principais pragas do trigo armazenado foi estudado por CAMPOS et al. (1991). Os seguintes tratamentos foram aplicados: deltametrina (0,35 e 0,70 ppm); malation (20 ppm); pirimifós-metil (4 e 8 ppm); fenitrotion (5 e $10 \mathrm{ppm})$ e as misturas de deltametrina e malation $(0,35$ e $20 \mathrm{ppm})$; deltametrina e pirimifós-metil (0,35 e 4,0 ppm); deltametrina e fenitrotion (0,35 e 5,0 ppm) e testemunha. Aos 180 dias da aplicação, concluíram que os fosforados foram eficientes no controle de S. oryzae e o piretróide no controle de $R$. dominica.

SCHROTER et al. (1991) controlaram R. dominica em grãos de trigo, aplicando dosagens de 0,$25 ; 0,50 ; 0,75$ e $1,0 \mathrm{ppm}$ de deltametrina, obtendo mortalidades superiores a 96,2\% até 390 dias da aplicaçåo. Pirimifós-metil na dosagem de 8,0 ppm, permitiu a sobrevivência da progênie da praga em 0,8 e 1,8 insetos por parcela de $40 \mathrm{~cm}^{3}$ de grãos aos 60 e 90 dias após o tratamento, respectivamente.

O controle de $R$. dominica em grãos de trigo armazenados foi estudado por LORINI \& SCHNEIDER (1993) com os tratamentos, fenitrotion $(5,0 ; 7,5$ e 10,0 ppm); pirimifós-metil (4; 6 e 8 ppm); deltametrina $(0,35 ; 0,45$ e $0,55 \mathrm{ppm})$; malation 
$(2 \mathrm{ppm})$ e fenitrotion $(7,5 \mathrm{ppm})+$ deltametrina $(0,35 \mathrm{ppm})$ por um período de 150 dias. Segundo os autores, nenhum dos tratamentos foi eficiente no controle da praga.

SANTOS \& WAQUIL (1993) testaram a eficiência de deltametrina $(0,5 ; 1,0$ e $2,0 \mathrm{ppm})$; fenitrotion e pirimifós-metil, ambos a 12,16 e $32 \mathrm{ppm}$, no controle de $S$. oryzae, $S$. zeamais e $R$. dominica em arroz armazenado. Os resultados mostraram que $R$. dominica somente foi controlada quando esteve presente o piretróide nos tratamentos, o mesmo ocorrendo com os gorgulhos quando os fosforados estiveram presentes. Como geralmente estas espécies ocorrem juntas em arroz armazenado, os pesquisadores recomendam que se utilize misturas destes dois grupos de inseticidas.

\subsection{Aspectos bioecológicos e danos de Rhyzopertha dominica e outros insetos em grãos armazenados}

A biologia de $R$. dominica em sorgo foi estudada por SATTIGI et al. (1985) em laboratório. Os estágios de ovo, larval, pré-pupal e pupal duraram de 5 a 9; 14 a 28; 1 a 2 e 5 a 8 dias, respectivamente, apresentando a espécie 4 ínstares larvais e um ciclo de vida de ovo a adulto de 25 a 47 dias.

FARONI \& GARCIA-MARI (1992) estudaram o tempo de desenvolvimento, sobrevivência e fecundidade de fêmeas de $R$. dominica a 18, 20, 24, 28, 32 e $35^{\circ} \mathrm{C}$ de temperatura e $80 \%$ de umidade relativa do ar em laboratório. O tempo de desenvolvimento decresceu com o aumento da temperatura e a sobrevivência larval variou 
de 40 a $70 \%$, sendo a máxima a $28^{\circ} \mathrm{C}$. A longevidade de fêmeas variou de 219 dias a $20^{\circ} \mathrm{C}$ a 75 dias a $35^{\circ} \mathrm{C}$ e a fecundidade aumentou com a temperatura, a um máximo de 423 ovos a $32^{\circ} \mathrm{C}$.

CAMPBELL \& SINHA (1976) relataram que S. granarius, $R$. dominica e Cryptolestes fermagineus (Coleoptera - Cucujidae) causaram 60, 17 e 4\% de perda de peso em grãos de trigo, respectivamente, durante a fase larval. C. fermugineus, $R$. dominica e $S$. granarius produziram 0,$57 ; 4,88$ e $4,77 \mathrm{mg}$ de fezes, respectivamente, nas fases larval e adulta, ou seja, as três espécies, na ordem, causaram nos grãos, perdas de peso de 4,47; 23,32 e $69,22 \%$.

DEMIANYK \& SINHA (1987) infestaram com 20 adultos de Prostephanus tnuncatus (Coleoptera - Bostrichidae) e R. dominica, $120 \mathrm{~g}$ de grãos de milho para avaliar as perdas. Após 20 semanas da infestação, $P$. tnuncatus e $R$. dominica produziram 25 e $14 \mathrm{~g}$ de poeira, correspondendo a 20,8 e $11,7 \%$ de perda de peso, respectivamente.

De acordo com LOPES et al. (1988) o aumento dos danos de grãos de milho por $S$. zeamais de $5 ; 20 ; 30 ; 40$ e $50 \%$, causou perdas de peso da ordem de $0 ; 5$; $8 ; 10$ e $13 \%$, respectivamente.

ROJAS-LEON (1988) relata que $R$. dominica, Xylobius parilis (Col., Bostrichidae), S. zeamais e Sitotroga cerealella (Lep., Gelechiidae) são consideradas pragas primárias de milho armazenado na região de La Frailesca, Chiapas, México.

CORRAL et al. (1992) relatam que das 33 espécies infestantes de cereais, encontradas em 6 armazéns rurais em Sonora, México, $R$. dominica e Tribolium castaneum foram as mais abundantes. 
FIELDS et al. (1993) citam que $R$. dominica tem distribuição cosmopolita e é a maior praga dos cereais armazenados. Os autores relataram que a infestação da praga nas Províncias do Canadá deve-se à importação de milho contaminado dos Estados Unidos. Segundo Storey et al. (1982) ${ }^{6}$, citados pelos autores, em 1990, foram importados em grãos de milho, 1.365.105 insetos de $R$. dominica e 45.752 insetos em trigo. Em 1991, 741.628 insetos foram coletados em milho e 4.637.808 em trigo, em 6 Províncias do Canadá.

${ }^{6}$ STOREY, C.L.; SAUER, D.B.; ECKER, O ; FULK, D.W. Insect infestation in wheat and corn exported from the U.S.A. Joumal of Econ. Entomology, College Park, 75: 827-32, 1982. 


\section{MATERIAL E MÉTODOS}

\subsection{Experimento de laboratório}

Os experimentos foram desenvolvidos no Setor de Toxicologia de Inseticidas do Departamento de Entomologia da Escola Superior de Agricultura "Luiz de Queiroz" da Universidade de São Paulo, em Piracicaba.

Os inseticidas foram aplicados em 06 de março de 1993 em duas dosagens, a saber: deltametrina (K-obiol $25 \mathrm{CE}$ ); 0,5 e 1,0 ppm; malation (Malatol 500 $\mathrm{CE}$ ); 20 e $40 \mathrm{ppm}$ e pirimifós-metil (Actellic $500 \mathrm{CE}$ ), 6 e $12 \mathrm{ppm}$. O delineamento experimental foi inteiramente ao acaso, com três repetições e os resultados foram analisados através de Análise de Regressão.

A aplicação foi realizada com um pulverizador acoplado a um compressor de ar marca DOVAT (1/3 c.v.) com pressão constante de $1,5 \mathrm{~kg} / \mathrm{cm}^{2}$, utilizando-se $10 \mathrm{ml}$ da solução inseticida para $2 \mathrm{~kg}$ de grãos de milho $(5 \mathrm{l} / \mathrm{t}) .0$ milho utilizado, do tipo semi-dentado amarelo, foi obtido no comércio local e apresentava cerca de $13 \%$ de umidade 
As amostragens para análise de resíduos foram feitas por um período de 180 dias, isto é, aos $0,30,60,90,120,150$ e 180 dias após o tratamento. $O$ total de amostras analisadas somaram 147, a saber: 3 produtos $\times 2$ dosagens $\times 3$ repetições $\times 7$ épocas, para um total de 126, além de 21 amostras testemunhas, totalizando-se 147.

O acompanhamento das condições no laboratório durante a condução dos experimentos foi feita através da coleta dos parâmetros climáticos do Posto Meteorológico do Setor de Física e Meteorologia da ESALQ (Figura 7), e da análise do grau de umidade dos grãos de milho nas parcelas testemunhas pelo método da estufa $\left(105^{\circ} \mathrm{C}\right.$ e 24 horas), no Laboratório de Sementes do Departamento de Agricultura da ESALQ, nas mesmas datas em que se amostrou para análise de resíduos.

\subsection{Atividade residual dos inseticidas sobre adultos de $\boldsymbol{R}$ dominica}

Para o estudo da atividade residual dos inseticidas sobre adultos de Rhyzopertha dominica, foram coletadas mensalmente de cada parcela experimental e nas mesmas datas de análise residual, amostras de cerca de 100 gramas de grãos do milho tratado, que foram colocados em frascos de vidro de $300 \mathrm{ml}$ de volume e infestadas com 40 adultos não sexados da praga com idade de 10 a 20 dias, obtidos de criação de laboratório. Após 15 dias da infestação avaliou-se a mortalidade, que foi comparada segundo Tukey 5\%. Sempre que necessário, utilizou-se a fórmula de Abbott |testemunha - tratamento|//100 - testemunha| para a correção da mortalidade. 
A avaliação do dano causado em grãos de milho por $R$. dominica foi feita através da infestação de peso conhecido de grãos de milho previamente expurgados com fosfina, com 10,20,30, 40 e 50 adultos não sexados por frasco de vidro de $300 \mathrm{ml}$ em quatro repetições e comparada com os danos causados pelo mesmo número do gorgulho S. zeamais, por um período de 120 dias, a partir de 20/05/94, sendo os resultados obtidos, analisados através de Análise de Regressão.

\subsection{Limites de deteç̧ão, porcentagem de recuperação e descrição dos métodos de análise de deltametrina, malation e pirimifós-metil em gräos de milho}

Para o estudo dos limites de detecção e porcentagens de recuperação dos inseticidas em grãos de milho, as amostras foram trituradas a fubá e fortificadas com as concentrações dos inseticidas nos níveis: 1,$0 ; 0,1 ; 0,05 ; 0,02 ; 0,01$ e 0,005 ppm, em 2 repetições.

Dois métodos analíticos foram utilizados, STORRHER et al., 1971 e MESTRES et al., 1978-79 e a determinação quantitativa foi feita por cromatografia a gás usando-se aparelho equipado com detector de ionização em chama alcalina (DICA) para os inseticidas organofosforados malation e pirimifós-metil, e de captura de elétrons (DCE) para o piretróide deltametrina. 
3.3.1. Análise de resíduos de malation e pirimifós-metil

O método foi adaptado de STORRHER et al., 1971, que é o método oficial para análise de resíduos de fosforados, cujas amostras foram submetidas à extração dos resíduos com uma mistura de acetonitrila + água; em seguida foi feita partição com diclorometano, seguindo-se a limpeza em coluna cromatográfica de carvão ativado, eluída com uma mistura de acetonitrila + benzeno. Segue-se a determinação quantitativa em cromatografia em fase gasosa.

\subsubsection{Reagentes}

Para as determinações mencionadas, foram empregados os seguintes

reagentes:

$$
\begin{aligned}
& \text { - acetonitrila - PA, ACS - GQ, 01019; } \\
& \text { - diclorometano - PA, ACS - GQ, 01003; } \\
& \text { - benzeno - PA, ACS - GQ, 01001; } \\
& \text { - acetona - PA, ACS - GQ, 01000; } \\
& \text { - água destilada; } \\
& \text { - Na } \mathrm{SO}_{4} \text { anidro - Reagen, 10150; } \\
& \text { - celite } 545 \text { - Nuclear, 1083; } \\
& \text { - carvão ativado - Merck, 2186.1000; }
\end{aligned}
$$


- óxido de alumínio Reagen, 10.352

- padrões analíticos de malation e pirimifós-metil.

\subsubsection{Aparelhos, vidrarias e outros materiais}

No presente trabalho de pesquisa, foram utilizados:

- cromatógrafo a gás, CG, modelo 3700 , equipado com detector de ionização em chama alcalina (DICA);

- coluna cromatográfica de vidro, diâmetro $1 / 8 "$, comprimento de 1,8m, empacotada com $5 \% \mathrm{QF}_{1} /$ Chrom W, AW-DMCS;

- evaporador rotativo a vácuo, Büchi, RE-121;

- moinho de laboratório, Marte;

- bomba pneumática Primar, 2 cv, modelo 141;

- mesa agitadora, Eberback;

- balança analítica; Helmac, modelo HM 10;

- microseringa - $10 \mu \mathrm{l}$, Hamilton;

- cronômetro, Technos;

- adaptador de vácuo, Kontes, modelo K-205000;

- frascos redondos de fundo chato, $500 \mathrm{ml}, 24 / 40$, Pyrex, $\mathrm{n}^{\circ} .410$;

- erlenmeyer com tampa esmerilhada, $250 \mathrm{ml}$, Pyrex, $\mathrm{n}^{\circ}$. 5020;

- coluna cromatográfica - vidro, $20 \times 300 \mathrm{~mm}$, porosidade grosseira,

provida com torneira de teflon; 
- funil de separação, $500 \mathrm{ml}$, Pyrex, $\mathrm{n}^{\circ} .6420$;

- funil de Buchner, $100 \mathrm{~mm}$ de diâmetro, Chiaroti;

- funil de vidro; 75 m m de diâmetro;

- quitassato, $500 \mathrm{ml}$, Pyrex, $\mathrm{n}^{\circ} .5340$;

- adaptador de borracha para filtragem;

- provetas graduadas, 100 e $500 \mathrm{ml}$;

- pipetas graduadas, 1 e $10 \mathrm{ml}$;

- papel de filtro, Covadis, 90 mm de diâmetro;

- rolhas de borracha perfuradas;

- papel aluminio, marca Rochedo;

- vidro âmbar, $15 \mathrm{ml}$, com tampa.

\subsubsection{Marcha analítica}

\section{a) Extraf̧ão}

a.1) Pesar $20 \mathrm{~g}$ de fubá obtido por moagem dos grãos de milho, colocar em erlenmeyer com tampa, juntar $100 \mathrm{ml}$ de uma mistura de acetonitrila + água (70 +30) e agitar em mesa agitadora por $5 \mathrm{~min}$.

a.2) Filtrar em funil de Büchner através de papel de filtro para o quitassato, com auxilio de vácuo fornecido pela bomba pneumática.

a.3) Lavar os conteúdos do erlenmeyer e os do funil de Büchner com mais $60 \mathrm{ml} \mathrm{da} \mathrm{mistura} \mathrm{acetonitrila}+$ água $(40+20)$. Transferir o extrato para uma proveta 
graduada e tomar metade dele, correspondente a $10 \mathrm{~g}$ da amostra, transferindo esta alíquota para o funil de separação de $500 \mathrm{ml}$; juntar igual volume de diclorometano e agitar vigorosamente por 30 segundos; deixar em repouso para a separação das fases. Passar a fase orgânica inferior para um balão de fundo chato de $500 \mathrm{ml}$, através de funil com $50 \mathrm{~g}$ de $\mathrm{Na}_{2} \mathrm{SO}_{4}$ anidro, suspenso em um funil de vidro.

\section{b) Limpeza}

b. 1) Preparar coluna cromatográfica de $20 \times 300 \mathrm{~mm}$ da seguinte maneira: conectando-se a coluna ao adaptador de vácuo, através de uma rolha de borracha furada e este a um balão de fundo chato de $500 \mathrm{ml}$; colocar $1 \mathrm{~g}$ de Celite 545 , ligar a linha de vácuo e fazer a acomodação com leves batidas de uma régua de madeira; fechar o vácuo; colocar $6 \mathrm{~g}$ da mistura adsorvente que tem a proporção $(1: 2: 4)$, respectivamente, de carvão ativado, óxido de alumínio e Celite 545; ligar a linha de vácuo fazendo nova acomodação; acrescentar camada de $1 \mathrm{~cm}$ de areia lavada de construção.

b.2) Pré-umidecer a coluna com $25 \mathrm{ml} \mathrm{da} \mathrm{mistura} \mathrm{acetonitrila} \mathrm{+}$ benzeno (1:1); eluir com auxílio de vácuo e descartar.

b.3) Transferir a camada orgânica proveniente do funil de separação para a coluna e eluir na velocidade de 80 a 120 gotas por minuto.

b.4) Extrair a camada aquosa do funil de separação com mais 2 vezes $10 \mathrm{ml}$ de diclorometano, transferindo cada fração para a coluna de limpeza, ao tempo em que a fração anterior tenha penetrado o nivel da areia. 
b.5) Finalmente, eluir a coluna com $120 \mathrm{ml}$ da mistura de acetonitrila + benzeno (1:1), recolhendo todos os eluados em um balão redondo de fundo chato de 500 $\mathrm{ml}$.

b.6) Evaporar em evaporador rotativo a vácuo em banho-maria a 75$80^{\circ} \mathrm{C}$ até $2-5 \mathrm{ml}$; evaporar o solvente remanescente com auxílio de vácuo.

\section{c) Determinação quantitativa}

c.1) Diluir os resíduos provenientes de b.6, lavando o frasco redondo com $5 \mathrm{ml}$ de acetona e recolher a lavagem em vidro âmbar de $15 \mathrm{ml}$.

c.2) Injetar alíquotas no cromatógrafo.

c.3) Condiçð̃es de operação do cromatógrafo:

Temperaturas:

$$
\begin{aligned}
& \text { coluna }=200 \text { e } 220^{\circ} \mathrm{C} \text { para pirimifós-metil e malation, } \\
& \text { respectivamente } \\
& \text { vaporizador }=270^{\circ} \mathrm{C} \\
& \text { detector (DICA) }=280^{\circ} \mathrm{C} \\
& \text { Fluxo de gases: } \quad \mathrm{N}_{2}=30 \mathrm{ml} / \text { minuto } \\
& \qquad \mathrm{AR}=210 \mathrm{ml} / \text { minuto } \\
& \mathrm{H}_{2}=40 \mathrm{ml} / \text { minuto }
\end{aligned}
$$

Atenuação de entrada: $10^{1}$ ou $10^{2}$

Atenuação de saída: 64 ou 128 vezes

Velocidade de registro $=0,25 \mathrm{pol} /$ minuto

Tempos de retenção:

$$
\begin{aligned}
& \text { pirimifós-metil }=2 \mathrm{~min} .20 \mathrm{seg} . \\
& \text { malation }=2 \mathrm{~min} .50 \mathrm{seg} .
\end{aligned}
$$


c.4) Cálculo dos resíduos. Os resíduos são calculados por comparação direta com os padrões, baseados nas alturas $(\mathrm{mm})$ dos picos dos padrões analíticos e amostras.

$$
\mathrm{ppm}=\frac{\mathrm{mp} \times \text { Ham }}{\text { Hp } \times \text { Mam }}, \quad \text { onde: }
$$

$\mathrm{mp}$ = massa injetada do padrão em ng;

Ham = altura do pico da substância na amostra, em mm;

$\mathrm{Hp}$ = altura do pico da substância no padrão, em mm;

Mam = massa da amostra injetada em mg.

\subsubsection{Análise de resíduos de deltametrina}

O método de análise, adaptado de MESTRES et al. (1978) e MESTRES et al. (1979) consta da extração dos resíduos das amostras com uma mistura de hexano e éter etílico, seguindo-se de partição com hexano e água. A limpeza do extrato foi feita em coluna cromatográfica de florisil, sendo a eluição procedida com a mistura de hexano + éter etílico; seguida da determinação quantitativa em cromatógrafo a gás equipado com detector de captura de elétrons (DCE). 


\subsubsection{Reagentes}

Para as determinações anteriormente mencionadas foram empregados os seguintes reagentes:

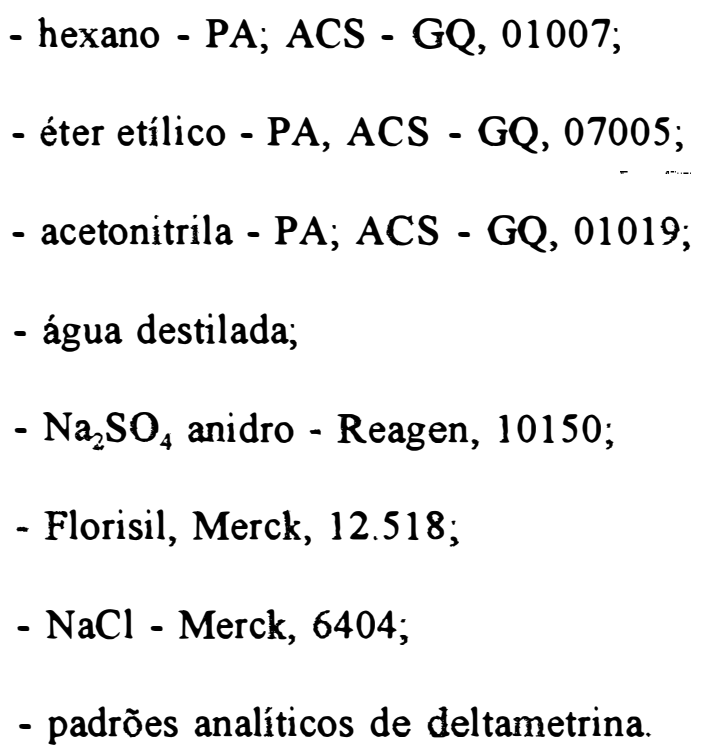

\subsubsection{Aparelhos, vidrarias e outros materiais}

Na presente pesquisa, foram utilizados:

- coluna cromatográfica de vidro de $0,7 \mathrm{~m}$, diâmetro $1 / 8^{\prime \prime}$ e empacotada com 2,5\% SE 30/Chrom W, AW - DMCS;

- cromatógrafo a gás, CG, modelo 3700, equipado com detector de captura de elétrons $\left(\mathrm{Ni}^{63}\right)$;

- outros aparelhos, vidrarias e materiais, semelhantes àqueles citados

no item 3.3.1.2. 


\subsubsection{Marcha analítica}

\section{a) Extraçāo}

a.1) Pesar $20 \mathrm{~g}$ de fubá obtido por moagem dos grãos e colocar em erlenmeyer de $250 \mathrm{ml}$, juntar $100 \mathrm{ml}$ da mistura de hexano e éter etílico (1:1) e agitar em mesa agitadora por $5 \mathrm{~min}$.

a.2) Filtar em funil de Büchner através de papel de filtro para um quitassato, com auxílio de vácuo fornecido pela bomba pneumática.

a.3) Lavar os conteúdos do erlenmeyer e os do funil de Büchner com mais $100 \mathrm{ml}$ da mistura de acetonitrila + éter etílico (1:1). Juntar os extratos e concentrar até 2 a $5 \mathrm{ml}$ em evaporador rotativo a vácuo em banho-maria a $75-80^{\circ} \mathrm{C}$.

a.4) Lavar os extratos concentrados do item a.3, contidos no balão de fundo chato com $50 \mathrm{ml}$ de hexano, colocar em funil de separação de $500 \mathrm{ml}$ contendo $400 \mathrm{ml}$ de água destilada e $30 \mathrm{ml}$ de água saturada com $\mathrm{NaCl}$. Agitar vigorosamente por 30 segundos, deixar em repouso para a separação das fases. Drenar a camada aquosa inferior para um erlenmeyer e passar a camada orgânica superior através de funil de vidro com cerca de $50 \mathrm{~g}$ de $\mathrm{Na}_{2} \mathrm{SO}_{4}$ anidro. Retornar a camada aquosa ao funil de separação e repetir a operação com mais $50 \mathrm{ml}$ de hexano. Concentrar os extratos em ERV, em banhomaria a $65-70^{\circ} \mathrm{C}$.

\section{b) Limpeza}

b. 1) Preparar coluna cromatográfica de $20 \times 300 \mathrm{~mm}$ provida de torneira de teflon, da seguinte maneira: adicionar pelo topo da coluna $6 \mathrm{~g}$ de florisil 
previamente ativado a $135^{\circ} \mathrm{C}$ por 2 dias e subsequentemente desativado com $5 \%$ de água, P.V.

b.2) Adicionar uma camada superior de $1 \mathrm{~g}$ de $\mathrm{Na}_{2} \mathrm{SO}_{4}$ anidro e lavar com $10 \mathrm{ml}$ de hexano, desprezando o eluado.

b.3) Diluir o extrato obtido em a.4 com $25 \mathrm{ml}$ de hexano e passar pela coluna cromatográfica.

b.4) Eluir a coluna com mais $130 \mathrm{ml}$ da mistura de hexano + éter etílico $(100+30)$ e coletar em balão de fundo chato. Concentrar o eluado em evaporador rotativo a vácuo em banho-maria a $65-70^{\circ} \mathrm{C}$.

\section{c) Determinação quantitativa}

c.1) Diluir os extratos provenientes de b.4, lavando o frasco redondo com hexano até obter $5 \mathrm{ml}$ de solução medidos em tubo de centrífuga graduado, guardando os resíduos em vidro âmbar de $15 \mathrm{ml}$ com tampa rosqueada.

c.2) Injetar alíquotas no cromatógrafo.

c.3) Condições de operação do cromatógrafo:

Temperaturas:

coluna: $230^{\circ} \mathrm{C}$

vaporizador: $270^{\circ} \mathrm{C}$

detector: $280^{\circ} \mathrm{C}$

Fluxo de $\mathrm{N}_{2}: 105 \mathrm{ml} / \mathrm{min}$

Atenuação de entrada: $10^{-8} \mathrm{~A}$ 
Atenuação de saída: 0,3 ou 1 vez

Velocidade de registro: $0,25 \mathrm{pol} / \mathrm{min}$.

Tempo de retenção: $2 \mathrm{~min} .30 \mathrm{seg}$.

\section{c.4) Cálculo dos resíduos}

Os resíduos são calculados por comparação direta com os padrões, baseados nas áreas $\left(\mathrm{mm}^{2}\right)$ dos picos dos padrões e amostras, de acordo com a fórmula abaixo apresentada:

$$
\mathrm{ppm}=\frac{\mathrm{mp} \times \mathrm{Aam}}{\operatorname{Ap} \times \mathrm{Mam}}, \text { onde: }
$$

$\mathrm{mp}=$ massa injetada da substância no padrão em ng;

Aam = área do pico da substância na amostra, em $\mathrm{mm}^{2}$;

Ap = área do pico da substância no padrão, em $\mathrm{mm}^{2}$;

Mam = massa da amostra de fubá injetada em $\mathrm{mg}$. 


\section{RESULTADOS E DISCUSSĀO}

\subsection{Resíduos de deltametrina em grãos de milho armazenados}

Os resultados obtidos das análises de grãos de milho feitas mensalmente de zero a 6 meses, para as dosagens de 0,5 e 1,0 ppm de deltametrina são apresentados na Tabela 3 e Figura 4.

$\mathrm{Na}$ Tabela 3 observa-se que das dosagens intencionais de 0,5 e 1,0 ppm de deltametrina, recuperou-se ao zero dia após a aplicação 0,45 e 0,85 ppm, ou seja, 90 e $85 \%$, respectivamente. HARGREAVES et al. (1982) recuperaram 90 e $84 \%$ das dosagens aplicadas de 0,5 e 1,0 ppm de deltametrina em grãos de trigo zero dia após o tratamento; NOBLE et al. (1982) o fizeram em 103 e 97,5\%, para as condições de $25^{\circ} \mathrm{C}$ e $12 \%$ de umidade e $35^{\circ} \mathrm{C}$ e $15 \%$ de umidade, respectivamente, zero dia após a aplicação de 2 ppm de deltametrina em grãos de trigo e BENGSTON et al. (1984) em $90 \%$ quando trataram grãos de sorgo com $2 \mathrm{ppm}$ do inseticida com butóxido de piperonila na mesma data de análise. 
A porcentagem de degradação do piretróide nas condições experimentais, seis meses após o tratamento foi de $69 \%$, para a dosagem de 0,5 ppm e $73 \%$ para a de 1,0 ppm. HARGREAVES et al. (1982) citam que 8 meses após a aplicação de deltametrina em grãos de trigo, apenas 14 e $8 \%$ das dosagens de 0,5 e 1,0 ppm aplicadas havia se degradado; NOBLE et al. (1982) citam degradações de 8,5 e $33 \%$ para duas condições de armazenamento, 6 meses após aplicação de 2 ppm do piretróide e BENGSTON et al. (1984) relatam degradação de $50 \%$ em grãos de sorgo, no mesmo período.

A legislação estabelece 1,0 ppm como limite máximo de resíduos para grãos armazenados e intervalo de segurança de 30 dias para produtos à granel, 7 dias para milho em espiga e 15 dias para produtos ensacados (GELMINI \& NOVO, 1987), o mesmo tendo sido citado por BITRAN et al. (1983).

A dosagem de deltametrina recomendada para controle de pragas em grãos de milho armazenados e a tolerância máxima permitida pela legislação apresentaram o mesmo valor, ou seja, 1,0 ppm. Assim sendo, pode-se entender que após a aplicação do piretróide em milho, este cereal pode ser consumido imediatamente, não necessitando respeitar nenhuma carência. Isso, obviamente, necessita ser melhor avaliado e entendido.

Os periodos de meias-vida das dosagens de 0,5 e $1,0 \mathrm{ppm}$ de deltametrina, nas condições experimentais foram 107 dias, com intervalo de confiança (I.C.) de $[51 ; 167]$ e 107 dias com I.C. de $[52 ; 169]$, respectivamente, com $95 \%$ de probabilidade (Figura 4). Estes periodos foram bem inferiores aos obtidos por SODERLAND \& CASIDA (1977), de 630 dias (15\% U) e NOBLE et al. (1982), de 798 dias (12\% U) e 245 dias (15\% U), em grão de trigo (Tabela 1). 
Tabela 3. Resíduos de deltametrina em grãos de milho tratados com 0,5 e $1,0 \mathrm{ppm}$ do inseticida, analisados mensalmente até 180 dias após aplicação.

\begin{tabular}{|c|c|c|c|c|c|c|}
\hline \multirow{2}{*}{ Tratamento } & \multirow{2}{*}{ DAT } & \multicolumn{3}{|c|}{ Repetições } & \multirow{2}{*}{$\begin{array}{l}\text { Média } \\
(\mathrm{ppm}) \\
\mathrm{m} \pm \mathrm{s}\end{array}$} & \multirow{2}{*}{$\begin{array}{c}\text { Degradação } \\
\text { residual } \\
(\%)\end{array}$} \\
\hline & & 1 & 2 & 3 & & \\
\hline \multicolumn{7}{|l|}{$-\cdots$} \\
\hline & 0 & 0,41 & 0,45 & 0,49 & $0,45 \pm 0,04$ & - \\
\hline & 30 & 0,25 & 0,29 & 0,33 & $0,29 \pm 0,04$ & 35 \\
\hline & 60 & 0,26 & 0,33 & 0,25 & $0,28 \pm 0,04$ & 38 \\
\hline Deltametrina & 90 & 0,21 & 0,24 & 0,25 & $0,23 \pm 0,02$ & 49 \\
\hline \multirow[t]{3}{*}{$0,5 \mathrm{ppm}$} & 120 & 0,20 & 0,22 & 0,22 & $0,21 \pm 0,01$ & 53 \\
\hline & 150 & 0,18 & 0,18 & 0,15 & $0,17 \pm 0,02$ & 62 \\
\hline & 180 & 0,12 & 0,16 & 0,15 & $0,14 \pm 0,02$ & 69 \\
\hline \multirow[t]{4}{*}{ Testemunha } & - & $\mathrm{ND}$ & ND & ND & - & - \\
\hline & 0 & 0,80 & 0,77 & 0,97 & $0,85 \pm 0,11$ & - \\
\hline & 30 & 0,68 & 0,63 & 0,59 & $0,63 \pm 0,04$ & 26 \\
\hline & 60 & 0,51 & 0,58 & 0,55 & $0,55 \pm 0,03$ & 35 \\
\hline Deltametrina & 90 & 0,45 & 0,50 & 0,52 & $0,49 \pm 0,04$ & 42 \\
\hline \multirow[t]{3}{*}{$1,0 \mathrm{ppm}$} & 120 & 0,40 & 0,29 & 0,35 & $0,35 \pm 0,05$ & 59 \\
\hline & 150 & 0,33 & 0,38 & 0,29 & $0,33 \pm 0,05$ & 61 \\
\hline & 180 & 0,24 & 0,23 & 0,23 & $0,23 \pm 0,01$ & 73 \\
\hline Testemunha & - & ND & ND & ND & - & - \\
\hline
\end{tabular}

DAT - Dias após tratamento

ND - Não detectável ou resíduos inferiores a $0,05 \mathrm{ppm}$

$\mathrm{m}=$ média

$\mathrm{s}=$ desvio padrão 


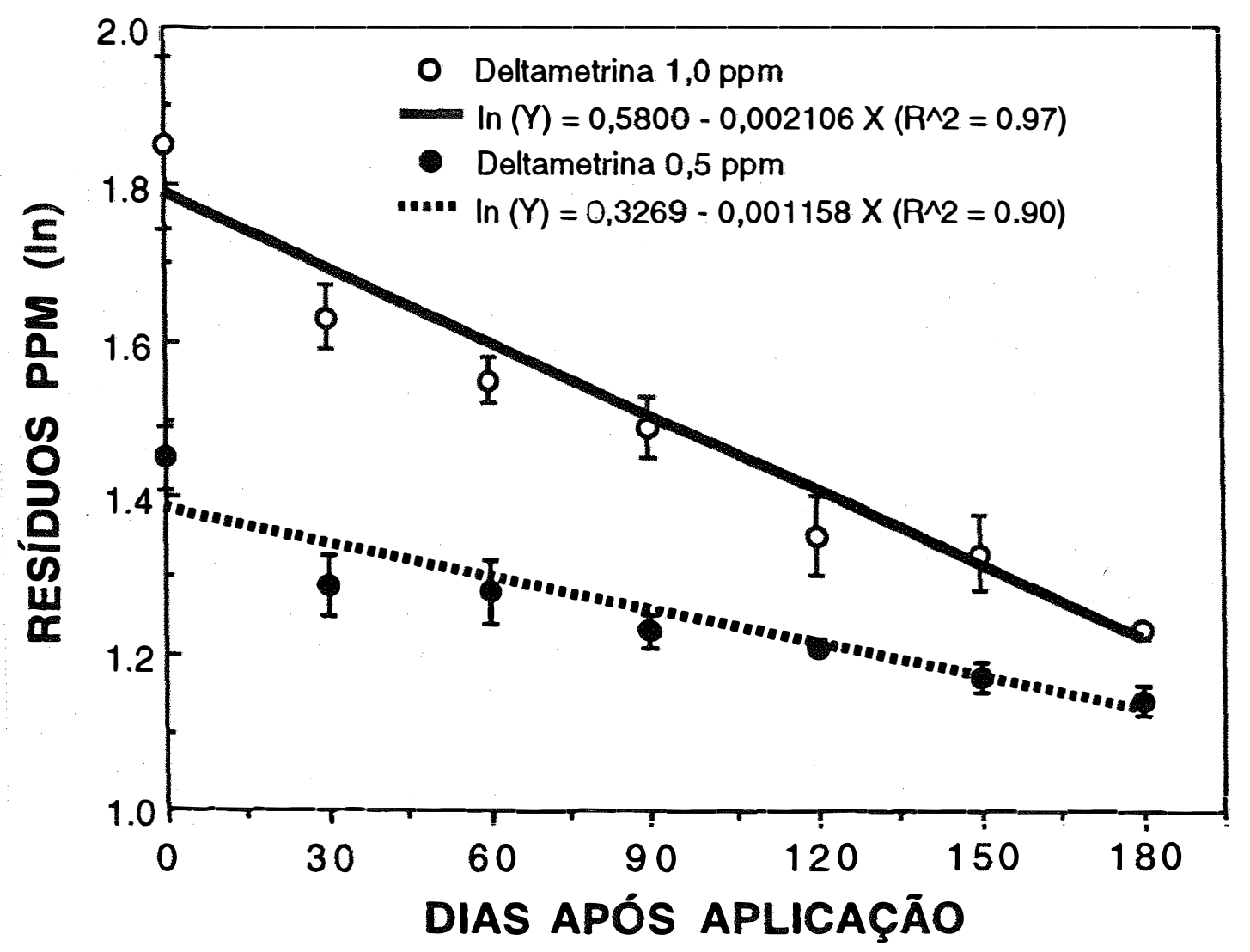

Figura 4. Curvas de degradação de resíduos de deltametrina em grãos de milho.

4.2. Resíduos de malation em grảos de milho armazenados

Os resultados obtidos nas análises de grãos de milho feitas mensalmente de zero a 6 meses, para as dosagens de 20 e 40 ppm são apresentados na Tabela 4 e Figura 5. 
Da Tabela 4 observa-se que das dosagens intencionais aplicadas de 20 e 40 ppm de malation, recuperou-se, zero dia após a aplicação, depósitos de 17,73 e 34,37 ppm, respectivamente, ou seja, 89 e $86 \%$. KIRKPATRICK et al. (1983) obtiveram depósito inicial de $110 \%$ da aplicação de $11 \mathrm{ppm}$ de malation em grãos de milho.

As porcentagens de degradação nas dosagens de 20 e 40 ppm de malation, 6 meses após o tratamento, foram 73 e 70\% respectivamente. COGBURN (1976) obteve $71 \%$ de degradação da dosagem de $14 \mathrm{ppm}$ de malation, no mesmo período em grãos de arroz, enquanto que MENSAH et al. (1979) obtiveram 63 e $88 \%$ de redução residual em grãos de trigo tratados com 12 ppm do fosforado e armazenados por 6 meses com 12 e $16 \%$ de umidade, respectivamente e KIRKPATRICK et al. (1983) o citam em $45 \%$ no mesmo período em grãos de milho.

A legislação estabelece 8 ppm de malation como limite máximo de resíduos em grãos de milho armazenados e uma carência de 60 dias (GELMINI \& NOVO, 1987). Os resultados das análises mostraram que utilizando a dosagem recomendada de 20 ppm do fosforado em grãos de milho, a tolerância máxima permitida somente seria atingida aos 138 dias após a aplicação (Tabela 4 e Figura 5). Este fato merece, também, ser investigado.

Os períodos de meias-vida das dosagens de 20 e $40 \mathrm{ppm}$ de malation foram 109 dias, com intervalo de confiança (I.C.) de $[101 ; 117]$ e 110 dias, com I.C. de [105; 113], respectivamente, com $95 \%$ de probabilidade (Figura 5). Estes periodos ficaram compreendidos entre àqueles obtidos por La HUE (1979), de 74 dias e de KADOWN \& la HUE (1975), de 180 dias (Tabela 1), quando aplicaram $10 \mathrm{ppm}$ do inseticida. 
Tabela 4. Resíduos de malation em grãos de milho tratados com 20 e 40 ppm do inseticida, analisados mensalmente até 180 dias após aplicação.

\begin{tabular}{|c|c|c|c|}
\hline \multirow[t]{2}{*}{ Tratamento } & \multirow[t]{2}{*}{ DAT } & Repetições & \multirow{2}{*}{$\begin{array}{c}\text { Degradação } \\
\text { residual } \\
(\%)\end{array}$} \\
\hline & & 1 & \\
\hline
\end{tabular}

\begin{tabular}{lrrrrrr}
\hline & 0 & 17,70 & 18,10 & 17,40 & $17,73 \pm 0,35$ & - \\
& 30 & 9,90 & 13,20 & 11,20 & $11,43 \pm 1,66$ & 35 \\
Malation & 60 & 8,45 & 8,51 & 11,00 & $9,32 \pm 1,46$ & 47 \\
20 ppm & 90 & 9,72 & 11,25 & 9,18 & $10,05 \pm 1,07$ & 43 \\
& 120 & 8,60 & 9,28 & 12,65 & $10,18 \pm 2,17$ & 43 \\
& 150 & 6,10 & 6,10 & 7,40 & $6,53 \pm 0,75$ & 63 \\
Testemunha & 180 & 3,29 & 5,55 & 5,61 & $4,81 \pm 1,32$ & 73 \\
& & & & & & \\
& - & ND & ND & ND & - & - \\
Malation & & & & & & \\
40 ppm & 0 & 32,50 & 33,20 & 37,40 & $34,37 \pm 0,25$ & - \\
& 30 & 23,90 & 23,70 & 24,20 & $23,93 \pm 0,25$ & 54 \\
& 60 & 21,42 & 21,33 & 22,18 & $21,64 \pm 0,47$ & 58 \\
Testemunha & 90 & 16,84 & 21,52 & 17,63 & $18,66 \pm 2,51$ & 64 \\
& 120 & 15,96 & 24,04 & 16,98 & $18,99 \pm 4,40$ & 64 \\
& 150 & 13,52 & 13,00 & 10,90 & $12,47 \pm 1,39$ & 76 \\
& 180 & 11,03 & 9,91 & 9,65 & $10,20 \pm 0,73$ & 80 \\
& & & & & & - \\
\hline
\end{tabular}

DAT - Dias após tratamento

ND - Não detectável ou resíduos a 0,01 ppm

$\mathrm{m}=$ média

$\mathbf{s}=$ desvio padrão 


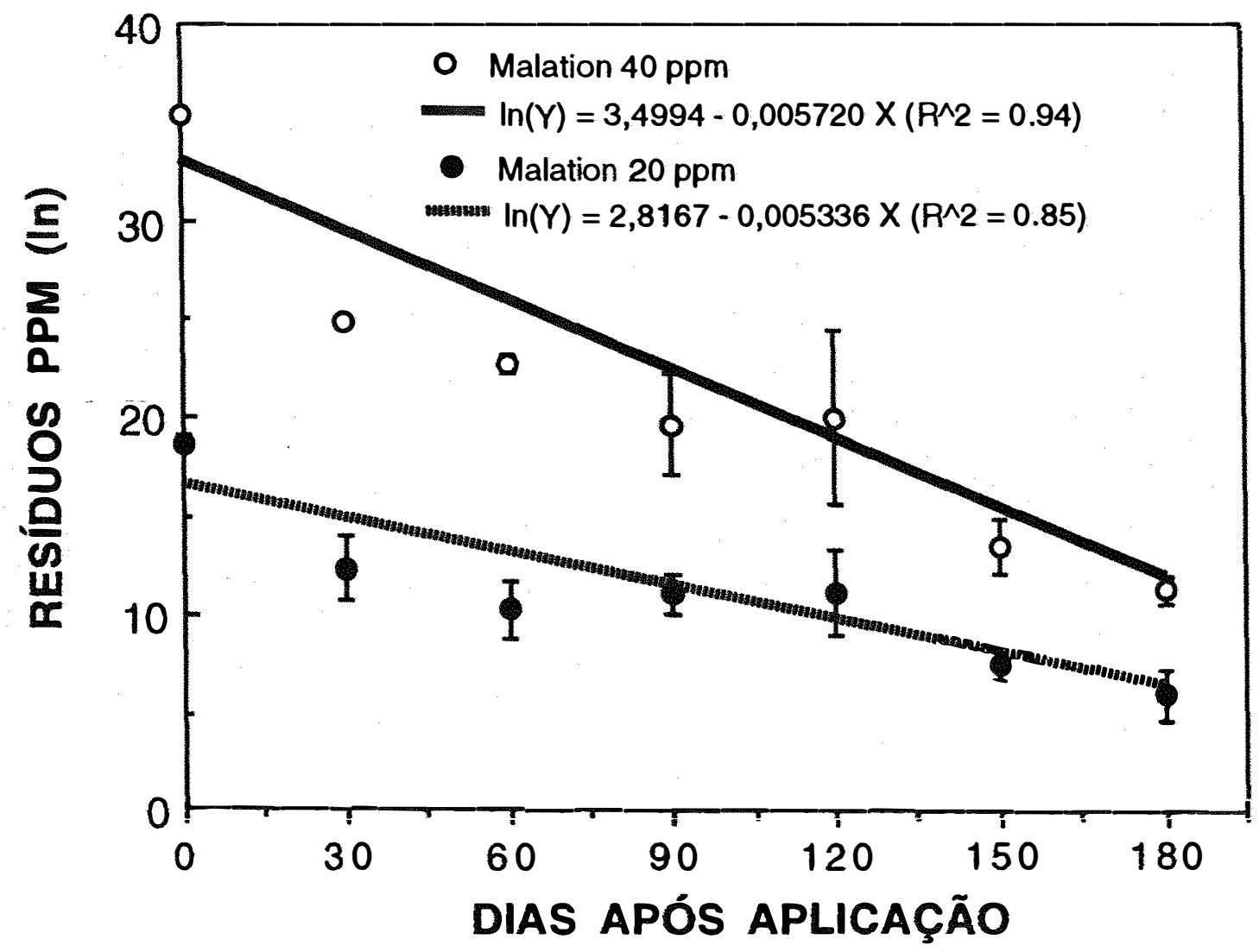

Figura 5. Curvas de degradação de resíduos de malation em grãos de milho.

\subsection{Resíduos de pinimifós-metil em grảos de milho armaenados}

Os resultados obtidos das análises de grãos de milho feitas mensalmente de zero a 6 meses, para as dosagens de 6 e 12 ppm de pirimifós-metil são apresentados na Tabela 5 e Figura 6. 
Da Tabela 5 observa-se que das dosagens intencionais de 6 e 12 ppm de pirimifós-metil, recuperou-se ao zero dia, depósitos de 4,02 e 9,25 ppm, ou seja, 67 e 77\%, respectivamente. DAVIES \& DESMARCHELIER (1981) obtiveram depósito de 85\% da dosagem de $6 \mathrm{ppm}$ do fosforado em grãos de trigo, 1 dia após a aplicação e BENGSTON et al. (1984) o fizeram em 108\% em grãos de sorgo, zero dia após a aplicação de 6 ppm de Actellic.

As porcentagens de degradação do fosforado nas condições experimentais para as dosagens de 6 e 12 ppm foram cerca de $75 \%$, e ambos os casos, 6 meses após a aplicação. BENGSTON et al. (1984) obtiveram degradação de $42 \%$ dos resíduos do inseticida em grãos de sorgo, 6 meses após o tratamento e SOWUNMI \& FETUGA (1985) o obtiveram em 70\% em grãos de milho, 5 meses após a aplicação de 20 ppm de fosforado.

A legislação estabelece para tratamento de grãos armazenados, tolerância e carência de 10 ppm e 30 dias, respectivamente (GELMINI \& NOVO, 1987). Como a dosagem recomendada de pirimifós-metil para controle de pragas em grãos armazenados é 6 ppm, certamente a aplicacão desta dosagem manteria níveis residuais inferiores a 10 ppm (tolerância máxima), mesmo logo após a aplicação, significando que os produtos tratados poderiam ser consumidos imediatamente após a aplicação, necessitando melhores estudos e/ou talvez adequação da legislação a essa e outras impropriedades.

Os periodos de meias-vida para as dosagens de 6 e $12 \mathrm{ppm}$ do fosforado, nas condições experimentais foram 130 dias, com intervalo de confiança (I.C.) de $[103 ; 161]$ e 93 dias, com I.C. de $[79 ; 108]$, respectivamente, com $95 \%$ de probabilidade.. Esta variação nos periodos de meias-vida do inseticida, de acordo com as 
diferentes dosagens aplicadas também foram encontradas por La HUE (1975) e COGBURN (1976). Para eles, com a aplicação de dosagens crescentes do fosforado em grãos de milho e arroz, respectivamente, tende-se a obter períodos de meias-vida também crescentes, resultados estes discordantes dos obtidos nesta pesquisa.

Estes períodos de meias-vida foram superiores aos encontrados por La HUE (1975) (77 a 90 dias), em grãos de milho, mas estiveram próximos dos encontrados por COGBURN (1976) (128 a 158 dias), em grãos de arroz, e foram inferiores aos obtidos por SOWUNMI \& FETUGA (1985) (365 dias), em milho.

\subsection{Considerações gerais sobre o comportamento dos resíduos dos inseticidas}

A análise das Tabelas 3, 4 e 5 e Figuras 4, 5 e 6 mostra que 6 meses após a aplicação, os três inseticidas apresentaram porcentagens de degradação semelhantes, ou seja, 69 e $73 \%$; 73 e $70 \%$ e 75 e $75 \%$, para deltametrina (0,5 e 1,0 ppm); malation (20 e $40 \mathrm{ppm}$ ) e pirimifós-metil (6 e $12 \mathrm{ppm})$, respectivamente.

Pirimifós-metil foi o inseticida que apresentou o menor depósito ao zero dia após a aplicação, ou seja, 67 e $77 \%$ das dosagens aplicadas de 6 e 12 ppm, enquanto que malation apresentou depósitos de 89 e $86 \%$ para 20 e 40 ppm e deltametrina 90 e $85 \%$ para 0,5 e $1,0 \mathrm{ppm}$, respectivamente. 
Tabela 5. Resíduos de pirimifós-metil em grãos de milho tratados com 6 e $12 \mathrm{ppm}$ do inseticida, analisados mensalmente até 180 dias após aplicação.

\begin{tabular}{|c|c|c|c|c|c|c|}
\hline \multirow{2}{*}{ Tratamento } & \multirow{2}{*}{ DAT } & \multicolumn{3}{|c|}{ Repetições } & \multirow{2}{*}{$\begin{array}{l}\text { Média } \\
(\mathrm{ppm}) \\
\mathrm{m} \pm \mathrm{s}\end{array}$} & \multirow{2}{*}{$\begin{array}{c}\text { Degradação } \\
\text { residual } \\
(\%)\end{array}$} \\
\hline & & 1 & 2 & 3 & & \\
\hline & 0 & 4,41 & 3,92 & 3,74 & $4,02 \pm 0,35$ & - \\
\hline & 30 & 2,43 & 2,21 & 2,12 & $2,25 \pm 0,16$ & 44 \\
\hline & 60 & 2,32 & 2,28 & 2,09 & $2,23 \pm 0,12$ & 44 \\
\hline Pirimifós-metil & 90 & 1,72 & 1,82 & 2,05 & $1,86 \pm 0,17$ & 54 \\
\hline \multirow[t]{3}{*}{$6 \mathrm{ppm}$} & 120 & 1,85 & 1,71 & 1,85 & $1,80 \pm 0,08$ & 55 \\
\hline & 150 & 1,42 & 1,32 & 1,37 & $1,37 \pm 0,05$ & 66 \\
\hline & 180 & 1,43 & 0,66 & 0,97 & $1,02 \pm 0,39$ & 75 \\
\hline \multirow[t]{4}{*}{ Testemunha } & - & ND & ND & ND & - & - \\
\hline & 0 & 10,00 & 8,23 & 9,52 & $9,25 \pm 0,92$ & - \\
\hline & 30 & 4,63 & 4,62 & 5,51 & $4,92 \pm 0,51$ & 47 \\
\hline & 60 & 3,88 & 4,62 & 4,18 & $4,23 \pm 0,37$ & 54 \\
\hline Pirimifós-metil & 90 & 3,36 & 4,61 & 3,96 & $3,98 \pm 0,63$ & 57 \\
\hline \multirow[t]{3}{*}{$12 \mathrm{ppm}$} & 120 & 3,15 & 3,53 & 4,68 & $3,79 \pm 0,80$ & 59 \\
\hline & 150 & 3,30 & 3,00 & 3,10 & $3,18 \pm 0,15$ & 66 \\
\hline & 180 & 1,89 & 2,36 & 2,50 & $2,25 \pm 0,32$ & 75 \\
\hline Testemunha & - & ND & ND & ND & - & - \\
\hline \multicolumn{7}{|c|}{ D.A.T. - Dias após tratamento } \\
\hline $\begin{array}{l}\text { N.D. - Não detec } \\
\mathrm{m}=\text { média } \\
\mathrm{s}=\text { desvio padrã }\end{array}$ & riores a & $0,01 \mathrm{pp}$ & & & & \\
\hline
\end{tabular}




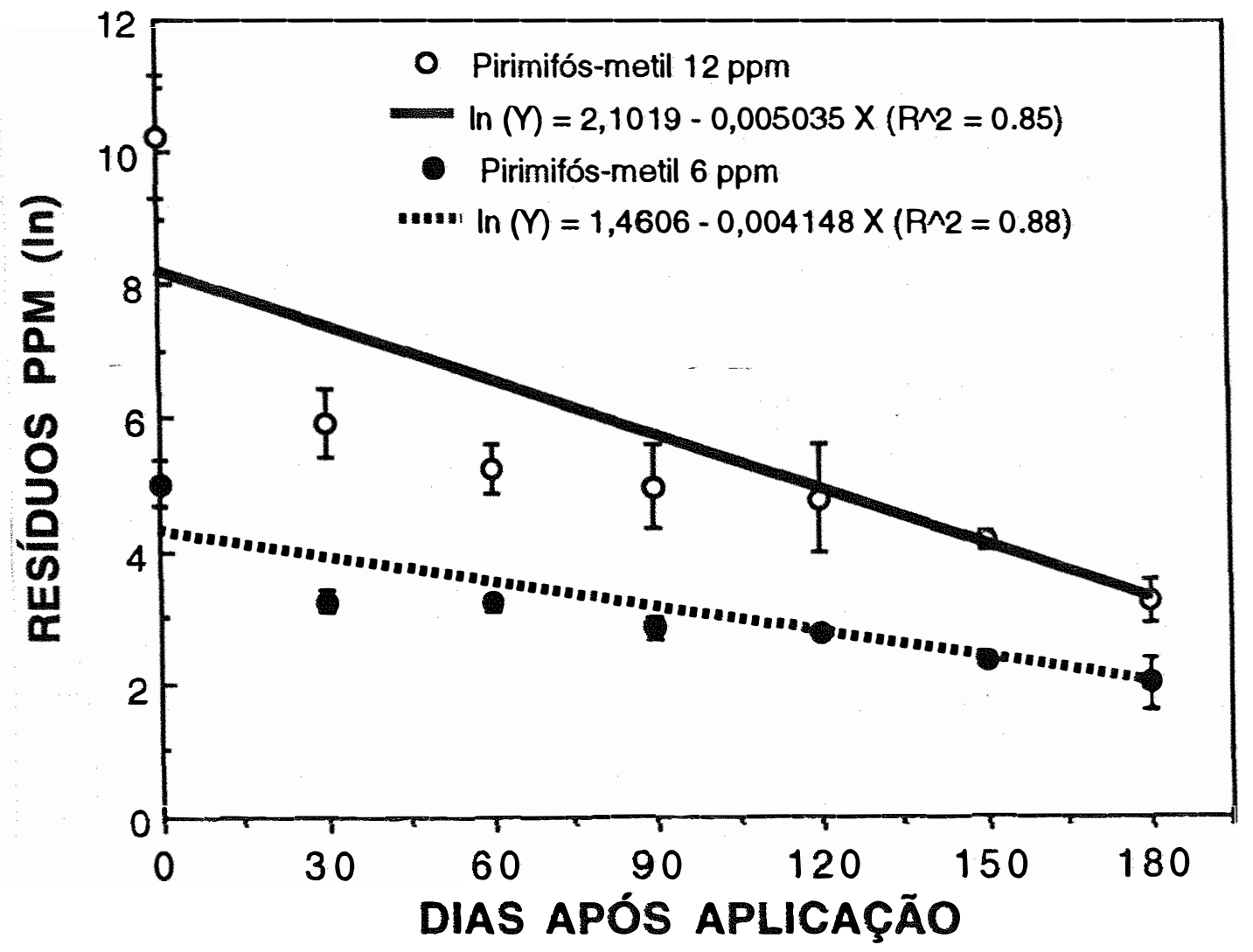

Figura 6. Curvas de degradação de resíduos de pirimifós-metil em grãos de milho.

No primeiro mês após a aplicação, a degradação foi mais rápida para pirimifós-metil, quando comparada com à dos outros dois inseticidas, o mesmo tendo ocorrido no $2^{\circ}$. e $3^{\circ}$. meses. Aos quatro meses, esta foi maior para deltametrina e pirimifósmetil e no $5^{\circ}$. e $6^{\circ}$. meses, esta se equiparou para os três inseticidas. 
As meias-vida de degradação das duas dosagens de deltametrina (0,5 ppm - 107 dias e 1,0 ppm - 107 dias), foram em média menores que as dosagens de malation (20 ppm - 109 dias e 40 ppm - 110 dias) e pirimifós-metil (6 ppm - 130 dias e 12 ppm - 93 dias). A ordem decrescente média de meia-vida de degradação foi pois: pirimifós-metil $>$ malation $>$ deltametrina.

De acordo com os limites máximos de resíduos e os intervalos de segurança estabelecidos pela legislação, verificou-se que apenas o intervalo de segurança de malation, nas condições experimentais, não esteve de acordo com as normas, que é de 60 dias, pois resíduos de 8 ppm foram atingidos somente aos 138 dias após a aplicação de 20 ppm do fosforado em grãos de milho.

\subsection{Análise de umidade de gräos de milho}

Os resultados da análise de umidade dos grãos de milho durante o período experimental se encontram na Tabela 6.

De acordo com os resultados da Tabela 6 , observa-se que houve diferença estatística significativa (Tukey 5\%) entre o grau de umidade dos grãos da análise feita aos 180 dias após o tratamento $(12,3 \%)$ e os resultados das análises feitas aos 30 e 90 dias (13,2\%), sendo que estas duas últimas não diferiram entre si. Observa-se na Figura 7 que em abril, mês em que se fez a análise de 30 dias após o tratamento, não ocorreram precipitações pluviais substanciais, o mesmo ocorrendo em junho, mês em que se fez a 
análise dos 90 dias, não havendo portanto correlação entre o maior teor de água dos grãos nestas datas de análise e precipitações. Provavelmente estas diferenças entre as médias das épocas de análise ocorreram devido às amostragens, e portanto não devem ter estas diferenças influenciado na degradação dos inseticidas estudados.

Tabela 6. Resultados de análise de umidade de grão de milho.

Grau de umidade (\%)

Tratamentos

$\begin{array}{lll}\mathbf{R}_{1} & \mathbf{R}_{2} & \mathbf{R}_{3}\end{array}$

Médias

DAT

$\mathbf{R}_{1}$

$R_{2}$

$\mathbf{R}_{\mathbf{3}}$

\begin{tabular}{rllll}
\hline 90 & 12,7 & 13,2 & 13,8 & $13,2 \mathrm{~A}$ \\
30 & 13,2 & 13,3 & 13,2 & $13,2 \mathrm{~A}$ \\
150 & 12,7 & 13,0 & 12,9 & $12,9 \mathrm{AB}$ \\
120 & 12,5 & 12,9 & 12,8 & $12,7 \mathrm{AB}$ \\
60 & 12,3 & 12,5 & 12,8 & $12,7 \mathrm{AB}$ \\
180 & 12,5 & 12,0 & 12,4 & $12,3 \quad \mathrm{~B}$ \\
\hline
\end{tabular}

$\mathrm{CV}=2,35 \%$

DAT - Dias após tratamento.

Médias seguidas de mesma letra não diferem estatisticamente ao nível de $5 \%$. 


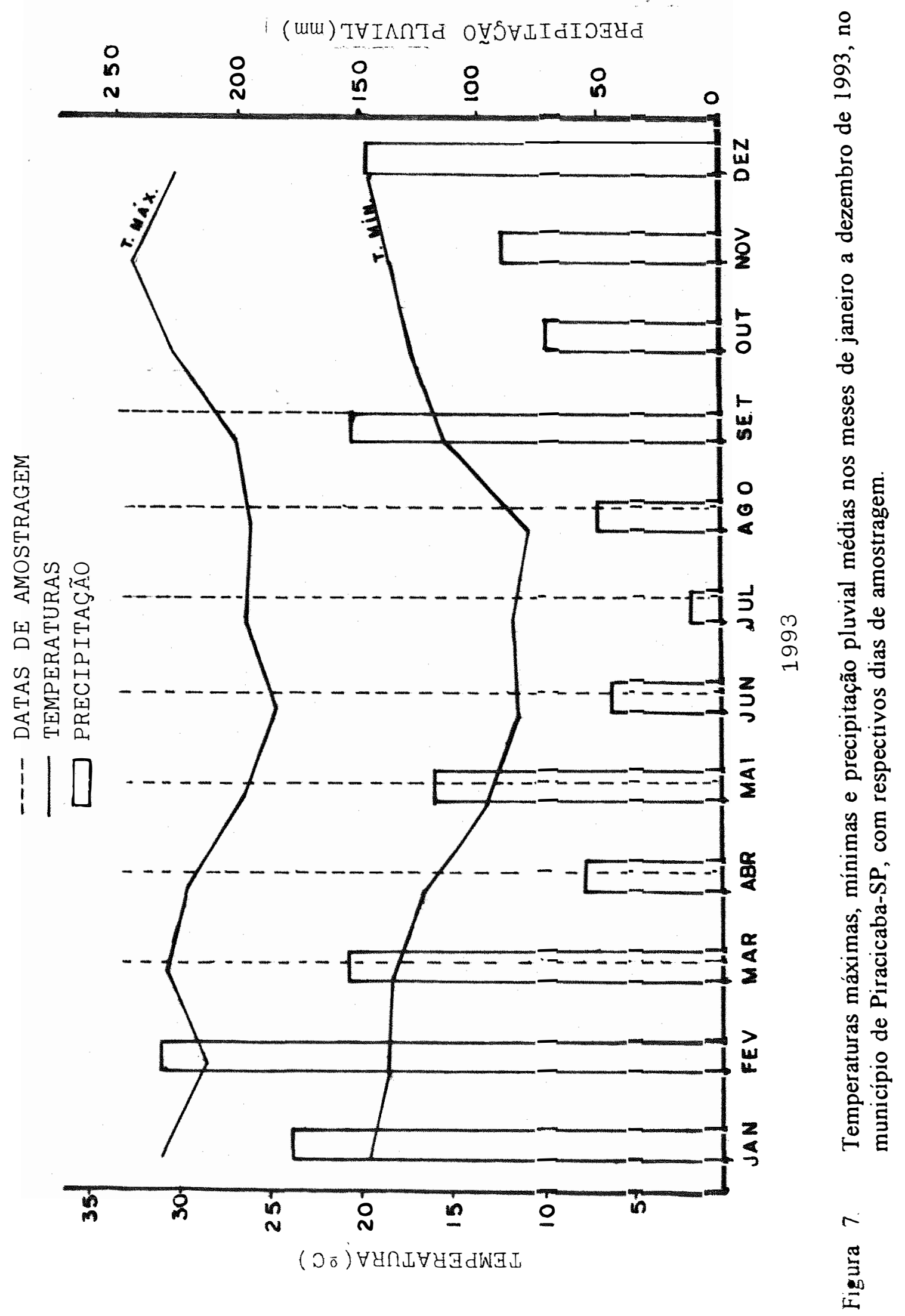


4.6. Efeito de deltametrina, malation e pirimifós-metil sobre os adultos de Rhyzopertha dominica

As Tabelas 7 e 8 e Figura 8 mostram os resultados de mortalidade de $R$. dominica infestada mensalmente em grãos de milho até 180 dias após os tratamentos, com avaliação 15 dias após a exposição.

Os resultados obtidos ao zero dia após a aplicação dos inseticidas nos grãos mostraram que somente as dosagens de 0,5 e 1,0 ppm de deltametrina (K-obiol 25 CE) foram eficientes no controle da praga, com $100 \%$ de mortalidade. A maior dosagem de pirimifós-metil (Actellic $500 \mathrm{CE}$ ) (12 ppm) proporcionou $88 \%$ de mortalidade, sendo os demais tratamentos ineficientes, mesmo quando se aplicou o dobro da dosagem, recomendada de malation (40 ppm), causando mortalidades inferiores a $50 \%$. Estes resultados são contrários aos obtidos por La HUE (1975), que controlou a praga com 10 ppm de malation e COGBURN (1976) com 14 ppm de malation ou 10 e 15 ppm de pirimifós-metil, sugerindo assim, algum nível de tolerância ou resistência atual a estes tratamentos.

De acordo com a análise estatística, todos os tratamentos nesta data (zero dia), diferiram da testemunha (Tukey 5\%), mas excetuando-se o piretróide e a maior dosagem de pirimifós-metil, todos os tratamentos foram ineficientes no controle de $R$. dominica. As maiores dosagens dos inseticidas foram utilizadas apenas experimentalmente, pois as recomendações oficiais deles para o controle de pragas em grãos armazenados são as menores dosagens utilizadas nesta pesquisa nos ensaios de resíduos, anteriormente relatados. 
Os resultados obtidos com infestação dos insetos aos 30 dias da aplicação, motraram que somente deltametrina foi eficiente no controle de $R$. dominica, pois os outros tratamentos causaram mortalidades menores que $20 \%$. Estes resultados são discordantes dos obtidos por COGBURN (1976) e KORUNIC \& HAMEL-KOREN (1985), em relação a pirimifós-metil.

As avaliações de mortalidade feitas após a infestação dos insetos aos $60,90,120,150$ e 180 dias do tratamento, mostraram resultados ineficientes, com exceção de deltametrina que controlou $100 \%$ da praga. Estes resultados foram discordantes dos obtidos por COGBURN (1976) que controlou R. dominica com 14 ppm de malation a $88 \%$, 3 meses após a aplicação e concordantes com o mesmo autor, que aos 6 meses não obteve êxito no controle da praga, o mesmo sendo afirmado por BENDECK et al. (1991) para malation e KORUNIC \& HAMEL-KOREN (1985) para pirimifós-metil.

A análise geral das Tabelas 7 e 8 e Figura 8 mostra que somente o piretróide foi eficiente no controle do besourinho dos grãos, mesmo com resíduos de 0,14 ppm aos 180 dias após o tratamento, observações concordantes com HSIEH et al. (1983), SAMSON \& PARKER (1989), CAMPOS et al. (1991) e SANTOS \& WAQUIL (1993), enquanto que SKARIA et al. (1989) relatam ineficiência no controle da praga com 0,75 e 1,0 ppm de deltametrina, o mesmo tendo sido citado por LORINI \& SCHNEIDER (1993). 
Tabela 7. Porcentagem de mortalidade de adultos de Rhyzopertha dominica, avaliada 15 dias após infestação.

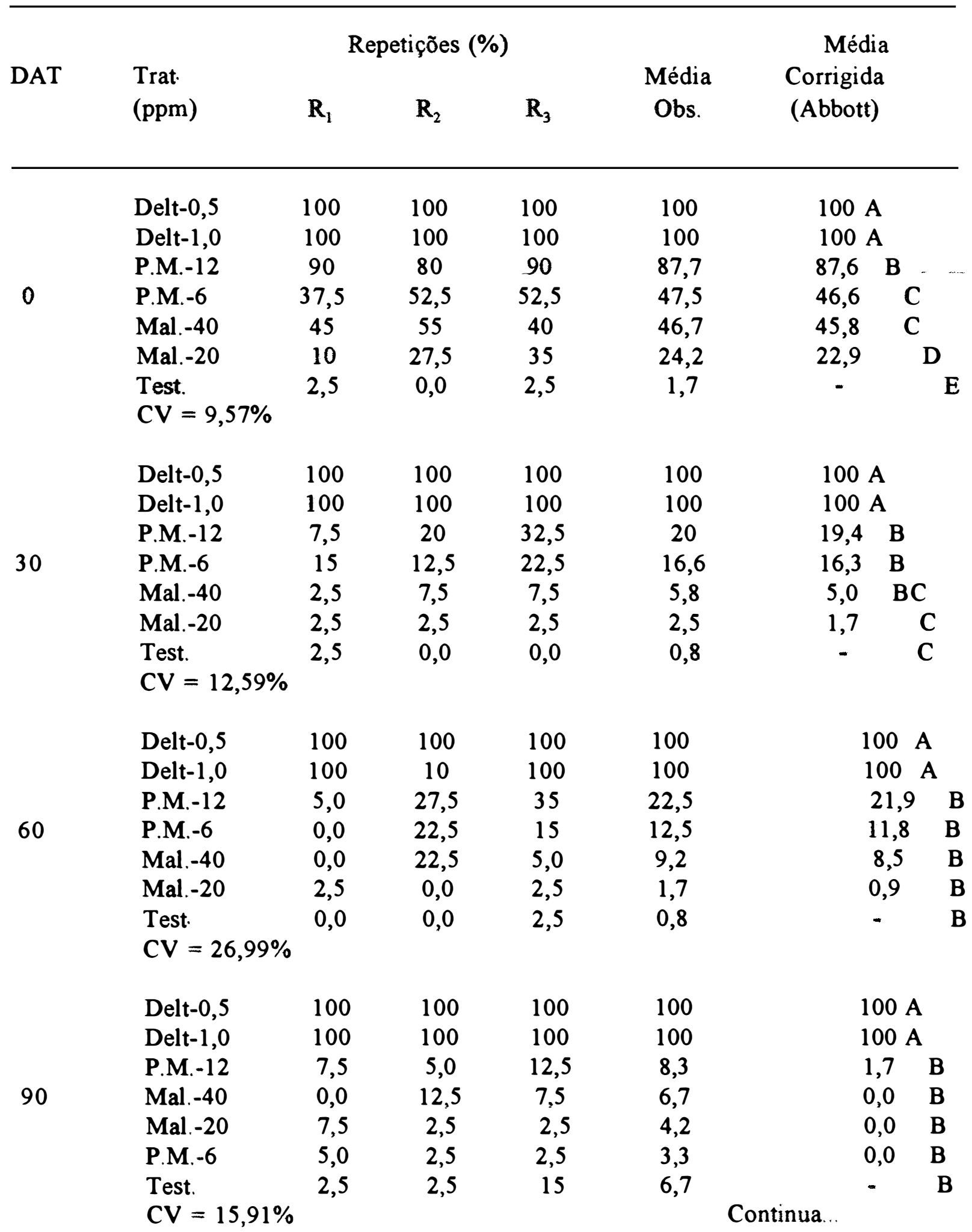


Tabela 7. Continuação.

\begin{tabular}{|c|c|c|c|c|c|c|}
\hline \multirow[b]{2}{*}{ DAT } & \multirow[b]{2}{*}{$\begin{array}{l}\text { Trat. } \\
\text { (ppm) }\end{array}$} & \multicolumn{3}{|c|}{ Repetições (\%) } & \multirow[b]{2}{*}{$\begin{array}{l}\text { Média } \\
\text { Obs. }\end{array}$} & \multirow[b]{2}{*}{$\begin{array}{c}\text { Média } \\
\text { Corrigida } \\
\text { (Abbott) }\end{array}$} \\
\hline & & $\mathbf{R}_{1}$ & $\mathbf{R}_{2}$ & $\mathbf{R}_{\mathbf{3}}$ & & \\
\hline \multirow{7}{*}{120} & Delt-0,5 & 100 & 100 & 100 & 100 & $100 \mathrm{~A}$ \\
\hline & Delt-1,0 & 100 & 100 & 100 & 100 & $100 \mathrm{~A}$ \\
\hline & Mal. -40 & 15 & 0,0 & 2,5 & 5,8 & $0,0 \quad \mathrm{~B}$ \\
\hline & P.M. -12 & 2,5 & 0,0 & 2,5 & 1,7 & $0,0 \quad B$ \\
\hline & P.M. -6 & 0,0 & 0,0 & 5,0 & 1,7 & $0,0 \quad B$ \\
\hline & Mal.-20 & 0,0 & 2,5 & 0,0 & 0,8 & $0,0 \quad B$ \\
\hline & $\begin{array}{l}\text { Test. } \\
\text { CV }=19,26 \%\end{array}$ & 5,0 & 12,5 & 7,5 & 8,3 & - B \\
\hline \multirow{7}{*}{150} & Delt $-0,5$ & 100 & 100 & 100 & 100 & $100 \mathrm{~A}$ \\
\hline & Delt-1,0 & 100 & 100 & 100 & 100 & $100 \mathrm{~A}$ \\
\hline & Mal.-40 & 15 & 7,5 & 35 & 19,2 & $9,4 \quad \mathrm{~B}$ \\
\hline & P.M.-6 & 15 & 10 & 10 & 11,7 & $0,0 \quad B$ \\
\hline & P.M. -12 & 12,5 & 10 & 0,0 & 7,5 & 0,0 \\
\hline & Mal.-20 & 2,5 & 2,5 & 2,5 & 2,5 & $0,0 \quad \mathrm{~B}$ \\
\hline & $\begin{array}{l}\text { Test. } \\
\text { CV }=16,34 \%\end{array}$ & 5,0 & 15 & 12,5 & 10,8 & - \\
\hline \multirow{7}{*}{180} & Delt $-0,5$ & 100 & 100 & 100 & 100 & $100 \mathrm{~A}$ \\
\hline & Delt-1,0 & 100 & 100 & 100 & 100 & $100 \mathrm{~A}$ \\
\hline & P.M. -12 & 2,5 & 7,5 & 10 & 6,7 & $5,1 \quad \mathrm{~B}$ \\
\hline & Mal.-20 & 5,0 & 2,5 & 5,0 & 4,2 & $2,5 \quad \mathrm{~B}$ \\
\hline & Mal.-40 & 10 & 2,5 & 0,0 & 4,2 & $2,5 \quad \mathrm{~B}$ \\
\hline & P.M. -6 & 2,5 & 0,0 & 7,5 & 3,3 & $1,6 \mathrm{~B}$ \\
\hline & $\begin{array}{l}\text { Test. } \\
\text { CV }=16,46 \%\end{array}$ & 0,0 & 2,5 & 2,5 & 1,7 & $-\mathrm{B}$ \\
\hline
\end{tabular}

DAT - Dias após tratamento

Delt - Deltametrina

Mal - Malation

P.M. - Pirimifós-metil

Médias seguidas de mesma letra não diferem estatisticamente entre si ao nível de $5 \%$. 
Tabela 8. Resíduos médios de deltametrina, malation e pirimifós-metil em grãos de milho e porcentagens de mortalidade média de Rhyzopertha dominica.

\begin{tabular}{|c|c|c|c|c|c|c|c|c|}
\hline \multicolumn{2}{|c|}{$\begin{array}{l}\text { Tratamento } \\
\text { DAT }\end{array}$} & \multirow{2}{*}{$\begin{array}{c}\text { Delt. } \\
0,5 \mathrm{ppm}\end{array}$} & \multirow{2}{*}{$\begin{array}{c}\text { Delt. } \\
\text { 1,0ppm } \\
0,85\end{array}$} & \multirow{2}{*}{$\begin{array}{c}\text { Malat. } \\
\text { 20ppm }\end{array}$} & \multirow{2}{*}{$\begin{array}{c}\text { Malat. } \\
40 \mathrm{ppm} \\
34,37\end{array}$} & \multirow{2}{*}{$\begin{array}{c}\text { Pir-met } \\
6 \mathrm{ppm} \\
4,02\end{array}$} & \multirow{2}{*}{$\begin{array}{c}\text { Pir.met } \\
12 \mathrm{ppm} \\
9,25\end{array}$} & \multirow{2}{*}{$\begin{array}{l}\text { Test. } \\
\text { ND }\end{array}$} \\
\hline 0 & Res. (ppm) & & & & & & & \\
\hline & Mort. (\%) & 100 & 100 & 22,9 & 45,80 & 46,6 & 87,5 & - \\
\hline \multirow[t]{2}{*}{30} & Res. (ppm) & 0,29 & 0,63 & 11,43 & 23,93 & 2,25 & 4,92 & ND \\
\hline & Mort. (\%) & 100 & 100 & 5,0 & 17,0 & 1,7 & 19,4 & - \\
\hline \multirow[t]{2}{*}{60} & Res. (ppm) & 0,28 & 0,55 & 9,32 & 21,64 & 2,23 & 4,23 & ND \\
\hline & Mort. (\%) & 100 & 100 & 0,9 & 8,5 & 11,8 & 21,9 & - \\
\hline \multirow[t]{2}{*}{90} & Res. (ppm) & 0,23 & 0,49 & 10,05 & 18,66 & 1,86 & 3,98 & ND \\
\hline & Mort. (\%) & 100 & 100 & 0,0 & 0,0 & 0,0 & 1,7 & - \\
\hline \multirow[t]{2}{*}{120} & Res. (ppm) & 0,21 & 0,35 & 10,18 & 18,99 & 1,80 & 3,79 & ND \\
\hline & Mort. (\%) & 100 & 100 & 0,0 & 0,0 & 0,0 & 0,0 & - \\
\hline \multirow[t]{2}{*}{150} & Res. (ppm) & 0,17 & 0,33 & 6,53 & 12,47 & 1,37 & 3,18 & ND \\
\hline & Mort. (\%) & 100 & 100 & 0,0 & 9,4 & 0,0 & 0,0 & - \\
\hline \multirow[t]{2}{*}{180} & Res. (ppm) & 0,14 & 0,23 & 4,81 & 10,20 & 1,02 & 2,25 & ND \\
\hline & Mort. (\%) & 100 & 100 & 2,5 & 2,5 & 1,6 & 5,1 & $=$ \\
\hline
\end{tabular}

DAT - Dias após o tratamento

ND - Não detectável. 

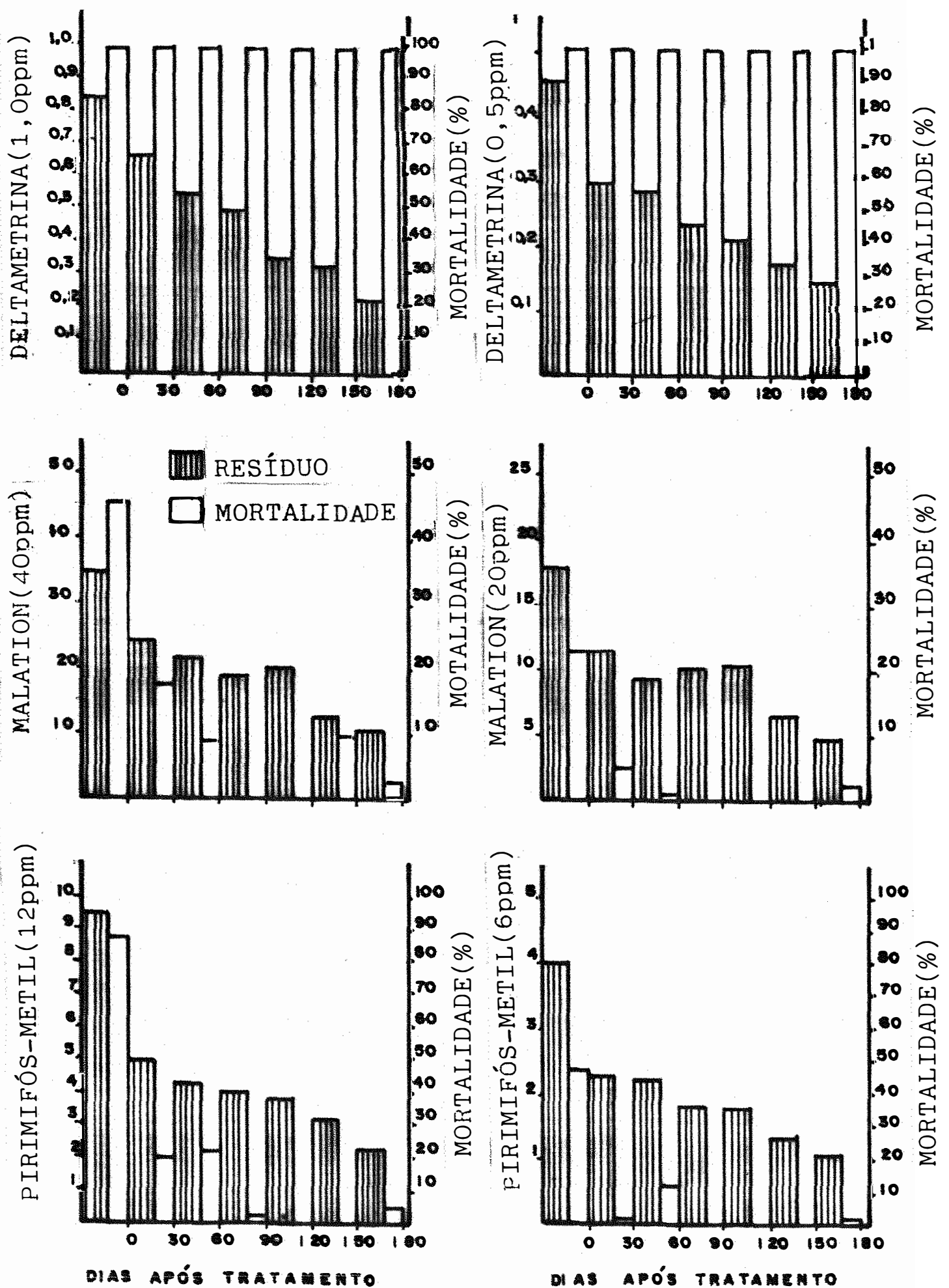

Figura 8. Resíduos médios de deltametrina, malation e pirimifós-metil e mortalidade de $R$. dominica em grăo de mi lho 
Os inseticidas fosforados foram ineficientes no controle de $R$. dominica, nas dosagens recomendadas, mesmo zero dia após o tratamento, resultados estes contrários dos obtidos por La HUE (1975), considerando malation, enquanto que CAMPOS et al. (1991) relatam que estes fosforados foram ineficientes no controle da praga, concordando com os resultados obtidos neste trabalho.

Geralmente a infestação de pragas em grãos armazenados é representada por diversas espécies de insetos, principalmente da ordem Coleoptera, dos gêneros Sitophilus, Rhyzopertha, Tribolium, etc. sendo necessário a mistura de fosforados com piretróides para um controle satisfatório destas pragas, pois os fosforados são eficientes no controle destes gêneros, exceto Rhyzopertha, que é eficientemente controlado com piretróides, observações estas citadas por CAMPOS et al. (1991) e SANTOS \& WAQUIL (1993).

A discussão dos resultados de controle de $R$. dominica obtidos pelos diversos pesquisadores citados no texto e no presente trabalho, em relação a deltametrina, malation e pirimifós-metil, mostra grandes divergências. Isto possivelmente se deve aos diferentes níveis de tolerância ou resistência aos inseticidas entre as populações de $R$. dominica utilizada nos experimentos, pois as dosagens dos inseticidas utilizados foram semelhantes, às usadas nesta pesquisa. 


\subsection{Danos causados por Sitophilus zeamais e Rhyzoperta dominica em grãos de milho armaenados}

Os resultados de danos causados por Rhyzopertha dominica e Sitophilus zeamais em grãos de milho armazenados por 4 meses, se encontram nas Tabelas 9 e 10 e Figuras 9 e 10.

Os resultados da Tabela 9 e Figura 9 mostram que $S$. zeamais apresentou em média danos de $8 ; 13 ; 16 ; 12$ e $11 \%$, quando se infestou $10,20,30,40$ e 50 adultos do inseto, respectivamente, em grãos de milho. Os danos foram crescentes até a infestação de 30 insetos por tratamento, atingindo um máximo de $16 \%$ de perda de peso, 4 meses após a infestacão, decrescendo quando se utilizou 40 ou 50 insetos por parcela, provavelmente devido à inibição no consumo provocada pela competição intraespecífica. A importância do gênero Sitophilus como causador de danos em cereais é discutida por CAMPBELL \& SINHA (1976), pois relatam que $S$. granarius causou 60 e $69 \%$ de perda de peso em grãos de trigo durante a fase larval e ciclo total de vida, respectivamente.

Os resultados da Tabela 10 e Figura 10 mostram que $R$. dominica causou danos de 2,$0 ; 2,7 ; 3,1 ; 2,6$ e $2,5 \%$ no peso dos grãos de milho durante 4 meses de armazenamento, quando se infestou 10,20,30,40 e 50 adultos do inseto por parcela, respectivamente. Os prejuizos foram crescentes até a infestação de 30 insetos por tratamento, atingindo um máximo de $3,1 \%$, decrescendo quando se utilizou 40 ou 50 insetos por parcela. Neste caso, provavelmente o excesso populacional também foi o fator que impediu a produção de maiores danos. 
Tabela 9. Peso (g) de grãos de milho antes e depois da infestação com Sitophilus zeamais e porcentagem (\%) de danos observados e corrigidos após 120 dias.

\begin{tabular}{|c|c|c|c|c|c|c|c|c|c|c|c|c|c|}
\hline \multirow{3}{*}{ Trat. } & \multicolumn{4}{|c|}{ Peso(g)/Repetições(AI) } & \multicolumn{4}{|c|}{ Peso(g)/Repetições(DI) } & \multicolumn{2}{|c|}{ Médias } & \multirow[t]{2}{*}{ Danos } & Danos & \multirow{2}{*}{$\begin{array}{l}\text { Danos } \\
\text { Corrig }\end{array}$} \\
\hline & & & & & & & & & & & & & \\
\hline & 1 & 2 & 3 & 4 & 1 & 2 & 3 & 4 & AI & DI & (g) & $(\%)$ & $\%$ \\
\hline $10^{*}$ & 80,1 & 79,3 & 85,2 & 83,9 & 69,6 & 75,3 & 73,8 & 73,9 & 82,1 & 73,1 & 8,9 & 10,94 & 8,3 \\
\hline 20 & 80,3 & 81,0 & 81,1 & 79,3 & 70,7 & 70,2 & 63,7 & 67,5 & 80,4 & 68,0 & 12,4 & 15,44 & 12,9 \\
\hline 30 & 81,7 & 80,5 & 80,2 & 82,2 & 73,4 & 61,0 & 61,7 & 69,9 & 81,2 & 66,5 & 14,7 & 18,08 & 15,7 \\
\hline 40 & 83,3 & 80,4 & 83,3 & 79,2 & 74,3 & 67,1 & 70,3 & 68,0 & 81,6 & 69,9 & 11,6 & 14,27 & 11,8 \\
\hline 50 & 84,4 & 80,8 & 81,2 & 78,1 & 73,9 & 67,8 & 73,2 & 66,7 & 81,2 & 70,4 & 10,8 & 13,28 & 10,8 \\
\hline Test. & 80,1 & 79,3 & 85,2 & 83,9 & 77,8 & 77,1 & 82,7 & 81,7 & 82,1 & 79,8 & 2,3 & 2,82 & - \\
\hline
\end{tabular}

AI - Antes da infestação

DI - Depois da infestação

* Número de adultos de $S$. zeamais por parcela.

Tabela 10. Peso (g) de grãos de milho antes e depois da infestação com Rhyzopertha dominica e porcentagem (\%) de danos observados e corrigidos, após 120 dias.

\begin{tabular}{|c|c|c|c|c|c|c|c|c|c|c|c|c|c|}
\hline \multirow{2}{*}{ Trat. } & \multicolumn{4}{|c|}{ Peso(g)/Repetiçס̃es(AI) } & \multicolumn{4}{|c|}{$\operatorname{Peso(g)/Repetiçס̃es(DI)~}$} & \multicolumn{2}{|c|}{ Médias } & Danos & Danos & $\begin{array}{l}\text { Danos } \\
\text { Corrig }\end{array}$ \\
\hline & 1 & 2 & 3 & 4 & 1 & 2 & 3 & 4 & AI & DI & (g) & $(\%)$ & $(\%)$ \\
\hline $10^{*}$ & 80,6 & 78,4 & 83,5 & 82,3 & 76,8 & 74,4 & 79,6 & 78,9 & 81,2 & 77,4 & 3,9 & 4,9 & 2,0 \\
\hline 20 & 82,6 & 79,8 & 78,7 & 79,5 & 78,6 & 75,5 & 74,6 & 74,6 & 80,1 & 75,8 & 4,4 & 5,4 & 2,7 \\
\hline 30 & 82,4 & 80,1 & 78,0 & 80,7 & 74,4 & 76,1 & 74,6 & 74,4 & 80,3 & 75,6 & 4,7 & 5,8 & 3,1 \\
\hline 40 & 76,4 & 75,6 & 80,4 & 79,6 & 72,5 & 71,3 & 76,2 & 75,4 & 78,0 & 73,8 & 4,2 & 5,4 & 2,6 \\
\hline 50 & 82,4 & 84,5 & 79,3 & 77,3 & 78,3 & 80,2 & 75,1 & 72,9 & 80,8 & 76,6 & 4,2 & 5,2 & 2,5 \\
\hline Test. & 80,1 & 79,3 & 85,2 & 83,9 & 77,8 & 77,1 & 82,7 & 81,7 & 82,1 & 79,8 & 2,3 & 2,8 & - \\
\hline
\end{tabular}

AI - Antes da infestação

DI - Depois da infestação

* Número de adultos de $R$. dominica por parcela. 


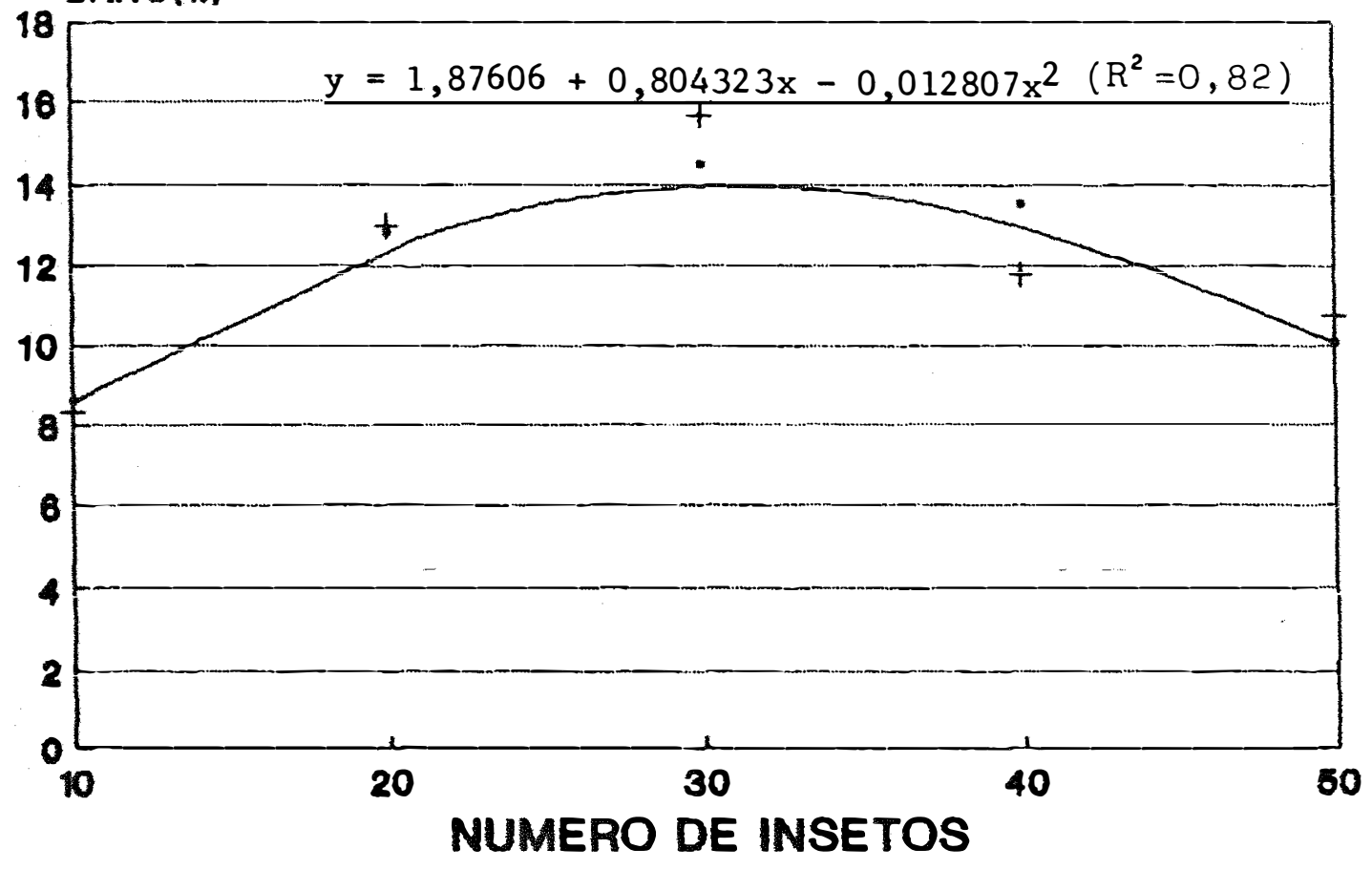

Figura 9. Danos (\%) de Sitophilus zeamais em grãos de milho.

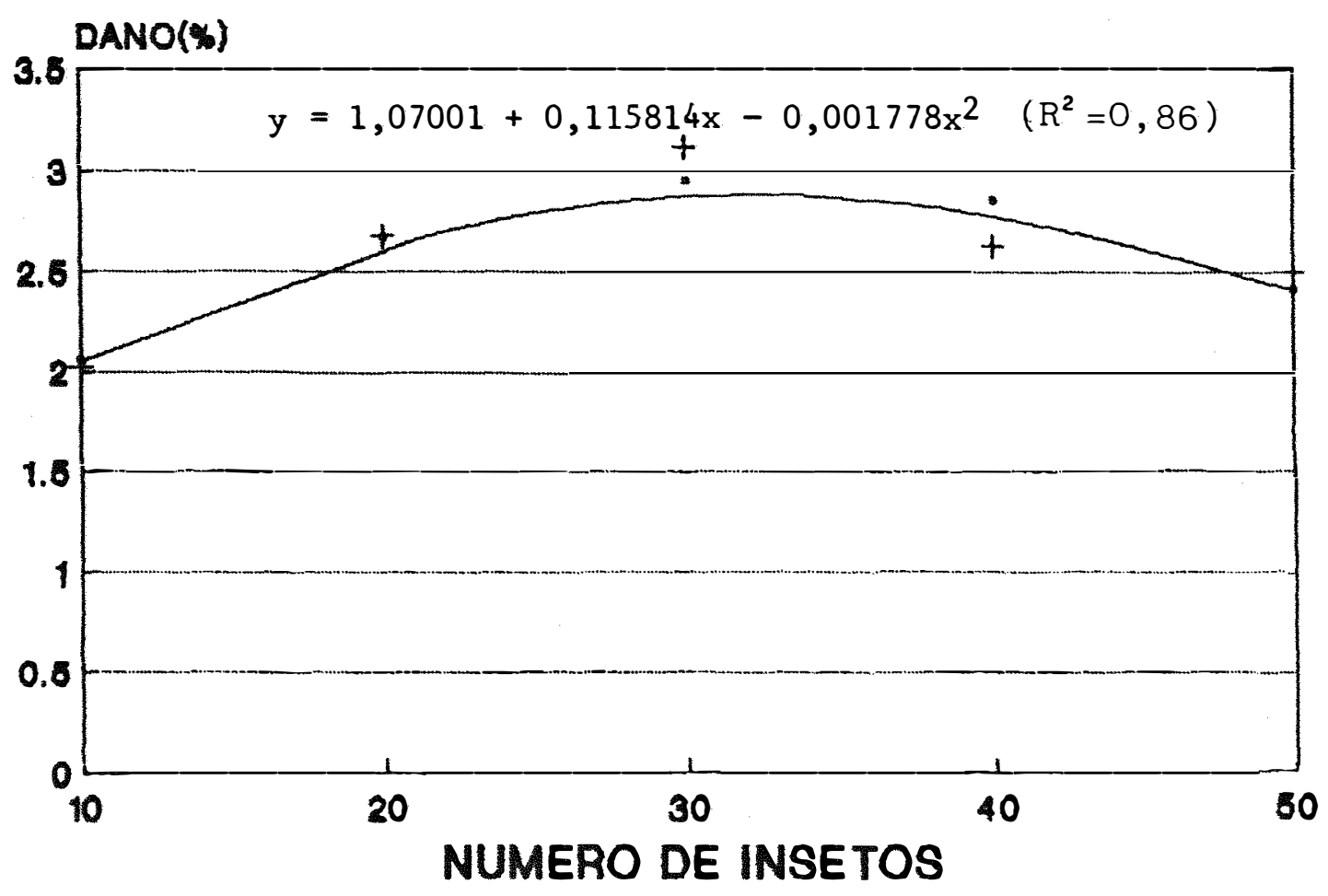

Figura 10. Danos (\%) de Rhyzopertha dominica em grãos de milho. 
O bostriquideo $R$. dominica é citado por CAMPBELL \& SINHA (1976) como causador de $17 \%$ de perda de peso em grãos de trigo durante a fase larval e $23 \%$ durante toda a vida. DEMIANYK \& SINHA (1987) também relatam que o besourinho dos grãos causou $12 \%$ de perda de peso em grãos de milho armazenados por 20 semanas, quando se infestou 20 adultos não sexados em 120 gramas do cereal. Outros autores, tais como ROJAS-LEON (1988), CORRAL et al. (1992) e FIELDS et al. (1993) citam a importância de $R$. dominica como causadora de grandes prejuízos em grãos de milho e outros cereais, quando presente nos armazéns.

\subsection{Limite de deteç̧ão e porcentagem de recuperação dos métodos}

Os resultados obtidos das porcentagens de recuperação de deltametrina, malation e pirimifós-metil em amostras de grãos de milho triturados a fubá e fortificadas como descrito anteriormente, são apresentados na Tabela 11. Os cromatogramas das fortificações de 0,05 ppm de deltametrina, $0,01 \mathrm{ppm}$ de malation e $0,02 \mathrm{ppm}$ de pirimifósmetil, bem como das testemunhas são mostrados nas Figuras 6, 7 e 8, respectivamente.

As amostras fortificadas com deltametrina revelaram porcentagens de recuperação que variaram de 81 a $111 \%$. Aquelas fortificadas com malation apresentaram recuperaç̃̃es de 90 a $129 \%$ e as fortificadas com pirimifós-metil de 99 a $129 \%$.

O limite de deteç̧ão para deltametrina neste substrato, foi estabelecido em $0,05 \mathrm{ppm}$, ou seja, a massa teórica deste inseticida injetada no cromatógrafo foi de $200 \mathrm{pg}$ (injeção de $1 \mu \mathrm{l}$ da amostra proveniente do item 3.3.2.3. c.1). Limites inferiores a este, 
devido às impurezas interferentes nos extratos, nas condições em que as análises foram executadas, seriam dificeis de serem quantificadas pelos picos nos cromatogramas.

Tabela 11.Porcentagem (\%) de recuperação de deltametrina, malation e pirimifós-metil pelos métodos de análise de resíduos em amostras de grãos de milho fortificațs

Níveis de fortificações (ppm)

Inseticidas Repetições

$\begin{array}{llllll}1,0 & 0,1 & 0,05 & 0,02 & 0,01 & 0,005\end{array}$

Deltametrina

A $\quad 111 \quad 90 \quad 95 \quad<$ LD $<$ LD $<$ LD $^{*}$

B

83

87

$81<$ LD $<$ LD $<$ LD

Malation

$\begin{array}{rrrrrrr}\text { A } & 98 & 129 & 90 & 92 & 92 & <\text { LD } \\ \text { B } & 110 & 127 & 103 & 104 & 101 & <\text { LD }\end{array}$

Pirimifós-metil

$\begin{array}{llllrll}\text { A } & 110 & 108 & 102 & 99 & 108 & <\text { LD } \\ \text { B } & 110 & 111 & 111 & 129 & 116 & <\text { LD }\end{array}$

* LD: limite de deteç̧ão. 


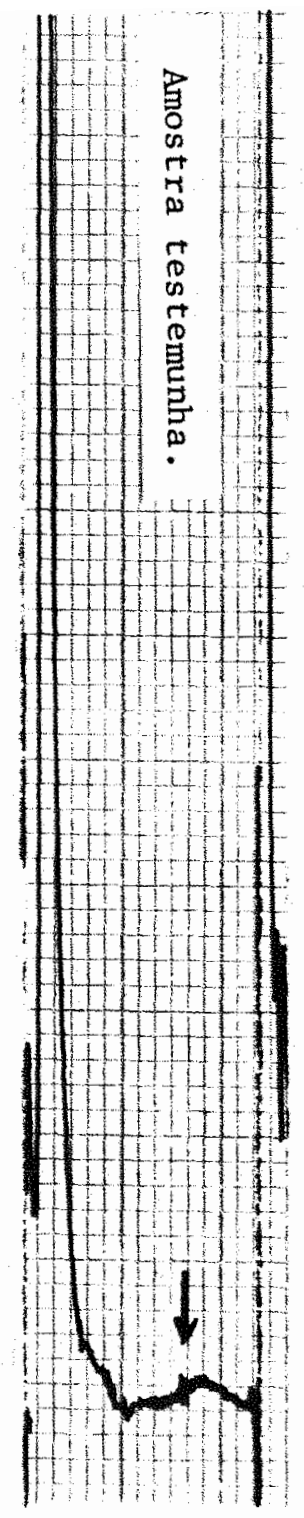

a

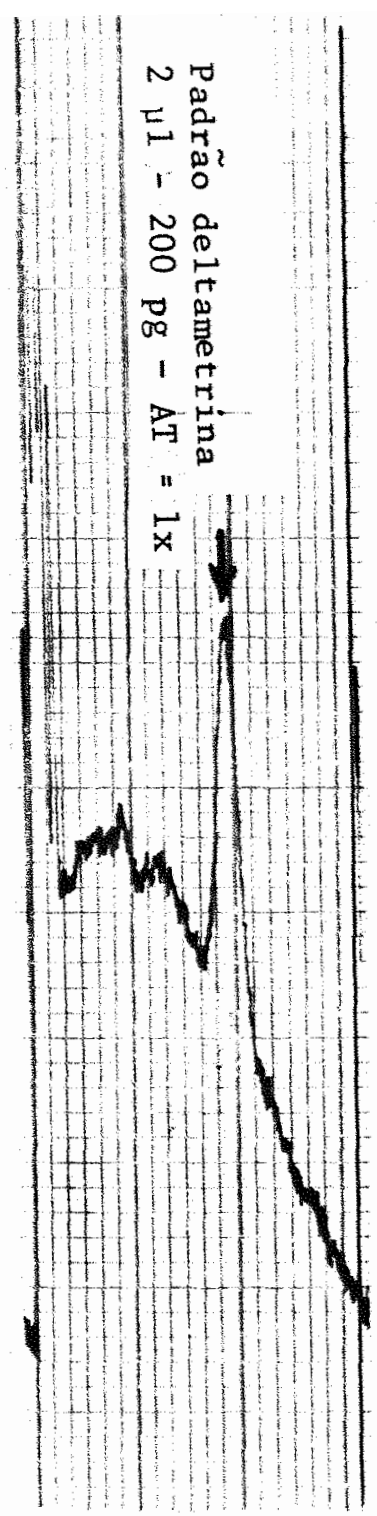

$\mathrm{b}$

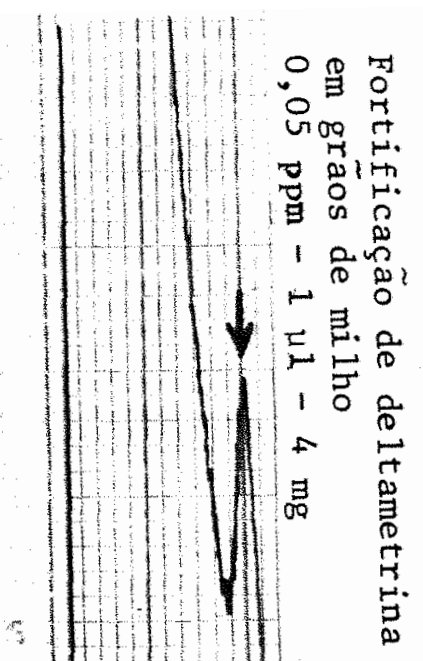

4

C

Figura 11. Cromatogramas: a) Amostra testemunha; b) Padrão analítico de deltametrina $(200 \mathrm{pg}) ; \mathrm{c})$ Amostra de grãos de milho fortificada com deltametrina $(0,05$ $\mathrm{ppm})$. 


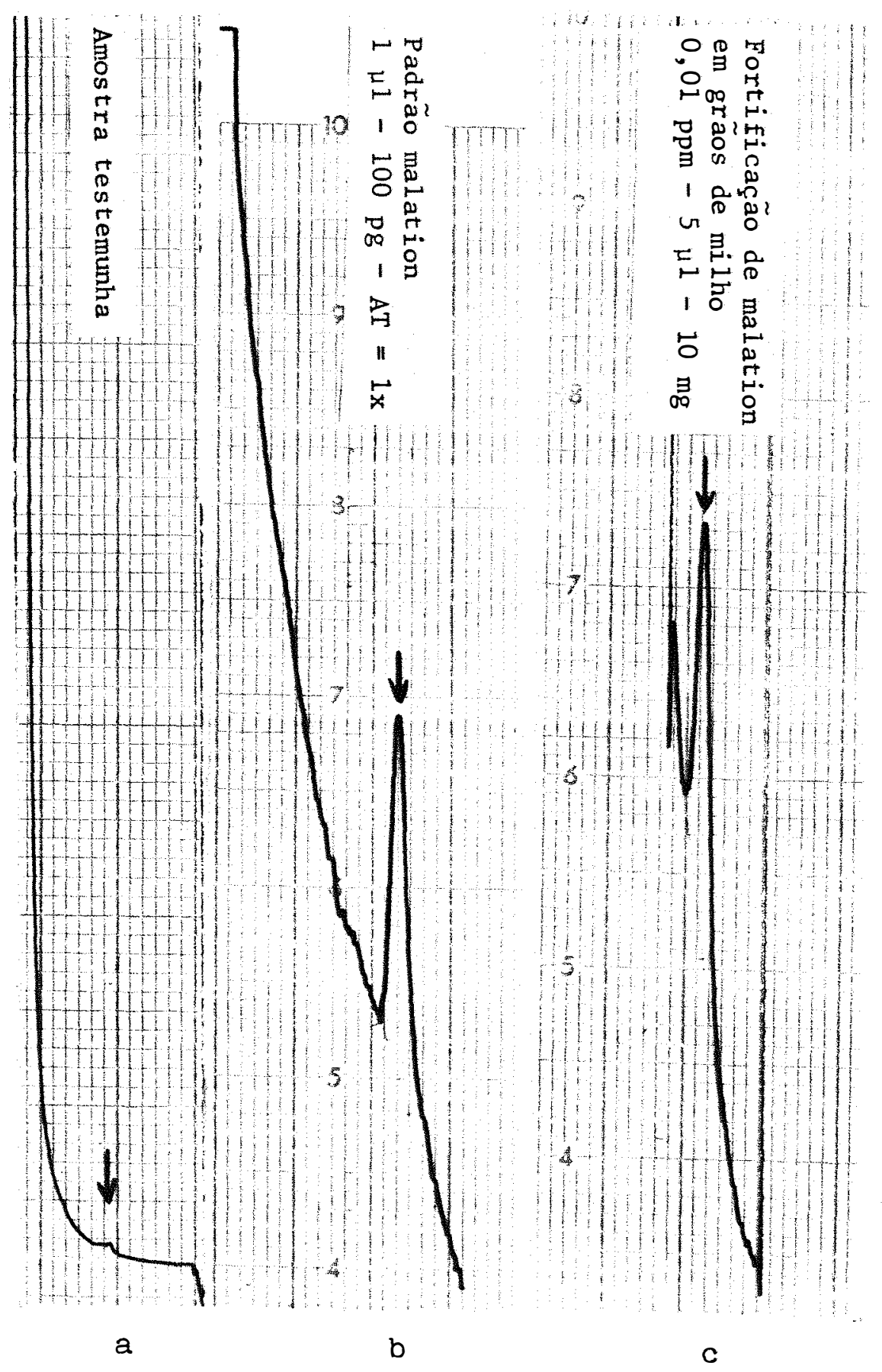

Figura 12. Cromatogramas: a) Amostra testemunha; b) Padrão analítico de malation $(100 \mathrm{pg})$; c) Amostra de grãos de milho fortificada com malation $(0,01 \mathrm{ppm})$. 


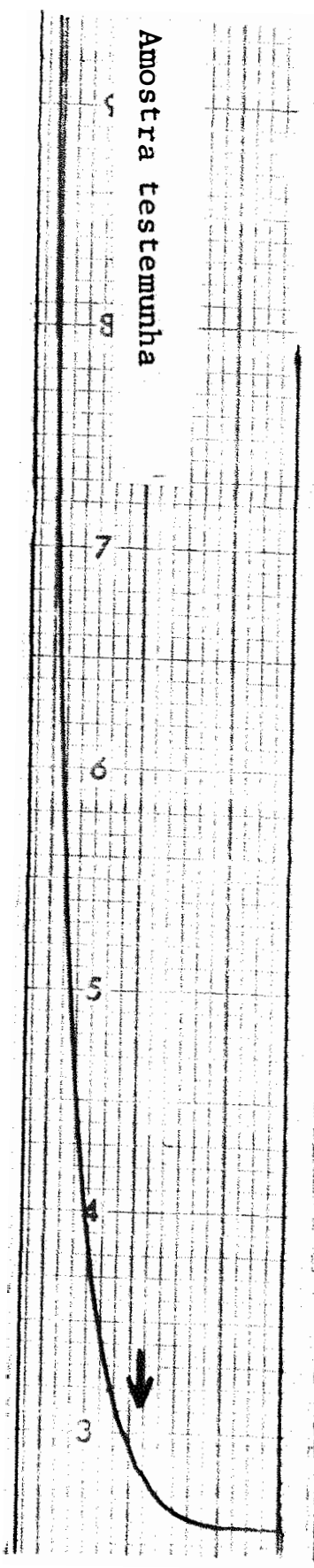

a

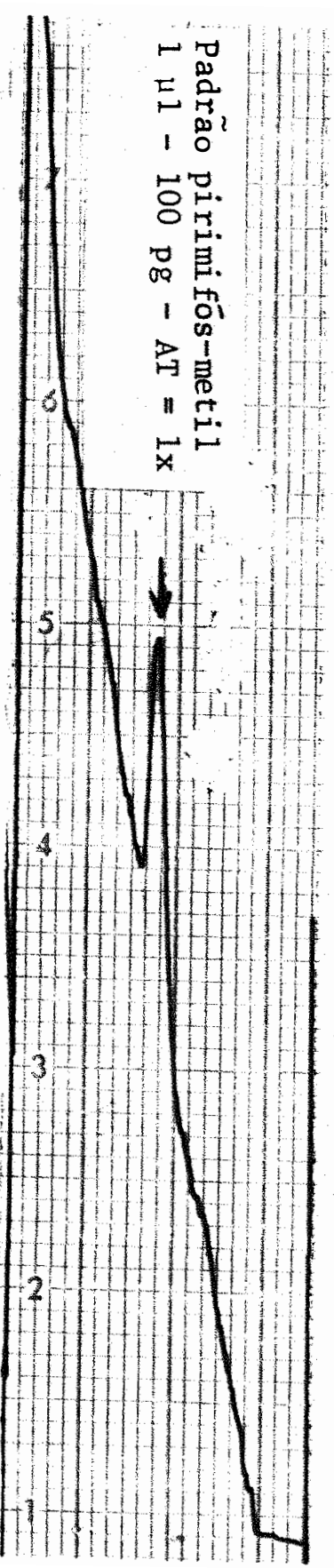

b

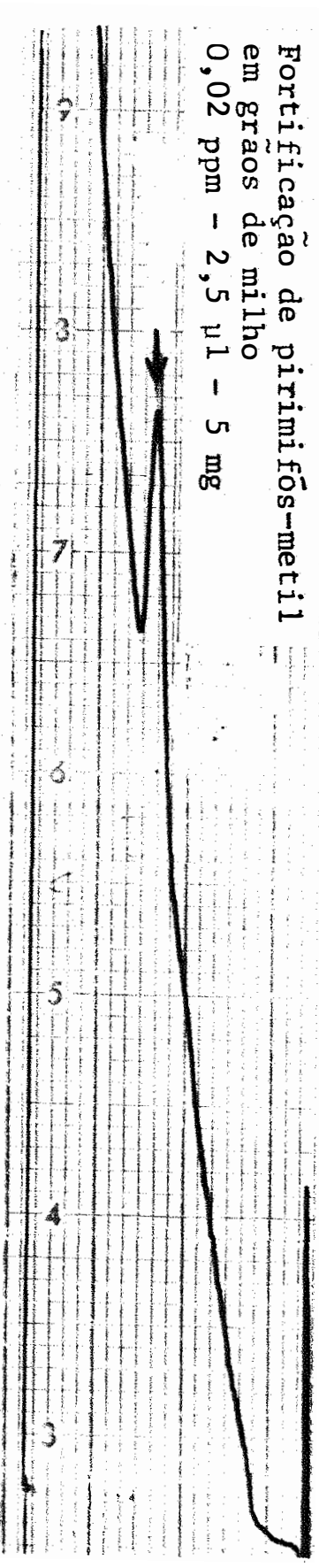

C

Figura 13. Cromatogramas: a) Amostra testemunha; b) Padrão analítico de pirimifósmetil (100 pg); c) Amostra de grãos de milho fortificada com pirimifós-metil $(0,02 \mathrm{ppm})$. 
O limite de detecção estabelecido para malation e pirimifós-metil em grãos de milho foi de 0,01 ppm, ou seja, a massa teórica destes inseticidas injetada no cromatógrafo foi de $100 \mathrm{pg}$ (injeção de $5 \mu \mathrm{l}$ da amostra proveniente de 3.3 .1 .3 c.1). 0 limite de deteç̧ão estabelecido para os fosforados foi cinco vezes inferior em relação ao piretróide. No caso dos fosforados, este limite ficou mais restrito à sensibilidade do aparelho, e sofreu menor influência das impurezas contidas nos extratos, pois além do detector (DICA) ser menos sensível à elas do que o DCE, o método de limpeza adotado para a análise dos fosforados foi mais eficiente.

Os métodos utilizados para a análise de resíduos mostraram-se relativamente simples, rápidos e econômicos, e adequados para a determinação quantitativa dos pesticidas utilizados, em grãos de milho. 


\section{CONCLUSÕES}

Nas condições em que foram realizados os experimentos, e de acordo com os resultados obtidos, pode-se concluir o seguinte:

a) O método analítico empregado para análise de resíduos de malation e primifós-metil em grãos de milho, mostra-se adequado, permitindo a deteç̧ão de níveis de resíduos de até $0,01 \mathrm{ppm}$.

b) $O$ método analítico empregado para análise de resíduos de deltametrina em grãos de milho, também mostra-se adequado, detectando níveis de resíduos de até $0,05 \mathrm{ppm}$.

c) O limite máximo de resíduos de deltametrina estabelecido para grãos de milho, necessita melhor adequação da legislação pertinente.

d) $O$ intervalo de segurança, necessário para se atingir o limite máximo de resíduos de malation em grãos de milho é superior ao estabelecido pela legislação 
e) O limite máximo de resíduos de pirimifós-metil estabelecido para grãos de milho é maior que a dosagem recomendada para controle de pragas neste cereal, necessitando também, melhor estudo e adequação da legislação.

f) Os períodos de meias-vida de degradação de deltametrina em grãos de milho foram ambos 107 dias para as duas dosagens utilizadas.

g) Os períodos de meias-vida de degradação de malation foram 109 e 100 dias para as dosagens de 20 e $40 \mathrm{ppm}$, respectivamente.

h) Os períodos de meias-vida de degradação de pirimifós-metil em grãos de milho foram 130 e 93 dias, para as dosagens de 6 e 12 ppm, respectivamente.

i) Os resíduos de pirimifós-metil foram os mais persistentes, seguidos de malation e deltametrina.

j) Dos três inseticidas utilizados, somente os resíduos de deltametrina foram eficientes no controle de $R$. dominica.

k) S. zeamais causou aproximadamente cinco vezes mais danos em grãos de milho, do que $R$. dominica. 


\section{REFERÊNCIAS BIBLIOGRÁFICAS}

ASTOLFI, E. \& LANDONI, J.H. de. Resíduos de defensivos em alimentos, avaliação toxicológica, estabelecimento de níveis máximos permitidos de resíduos (tolerâncias), aditivos alimentares. In: CURSO SOBRE TOXICOLOGIA DE DEFENSIVOS AGRÍCOLAS, 3., São Paulo, 1984. ANDEF, 1984. São Paulo, p.83-103.

BARETH, S.S. \& GUPTA, H.C. Efficacy of gunny bag and seed treatment on the natural infestation of Rhyzopertha dominica on stored wheat. Seed Research, New Delhi, 17(2): 178-81, 1989. Apud Review of Agricultural Entomology. Ser. A, Wallingford, 80(2): 178, Feb. 1992. (Resumo).

BENDECK, O.R.P.; MACUL, L.F.; NAKANO, O. Efeito de K-obiol 2P no controle de Rhyzopertha dominica (Fabr., 1792) (Col., Bostrichidae) em grãos de trigo armazenados. In: CONGRESSO BRASILEIRO DE ENTOMOLOGIA, 13, Recife, 1991. Resumos. Recife, SEB, 1991. p.466.

BENGSTON, M.; COOPER, L.M.; DAVIES, R.A.; DESMARCHELIER, J.M.; HART, R.H.; PHILLIPS, M.P. Grain protectants for the control of malathion - resistant insects in stored sorghum. Pesticide Science, Oxford, 14: 385-98, 1983.

BENGSTON, M.; DAVIES, R.A.H.; DESMARCHELIER, J.M.; PHILIPS, M.P.; SIMPSON, B.W. Organophosphorus and synergized synthetic pyrethroid insecticides as grain protectants for stand sorghum. Pesticide Science, Oxford, 15: 500-8, 1984. 
BITRAN, E.A.; CAMPOS, T.B.; OLIVEIRA, D.A.; CHIBA, S. Avaliação da eficiência residual do piretróide deltametrina em grãos armazenados. O Biológico, São Paulo, 49(9/10): $237-46,1983$.

CAMPBELL, A. \& SINHA, R.N. Damage of wheat by feeding of some stored product beetles. Joumal of Economic Entomology, Baltimore, 69(1): 11-3, 1976.

CAMPOS, T.B.; BITRAN, E.A.; GEBARA, A.B. Controle de Sitophilus oryzae (L., 1765) (Col. Curculionidae) e Rhyzopertha dominica (Fabr., 1792) (Col. Bostrichidae) em armazém graneleiro. In: CONGRESSO BRASILEIRO DE ENTOMOLOGIA, 13, Recife, 1991. Resumos, Recife, SEB, 1991. p.459.

CAVERO, E.S.; GUERRA, M. S.; SILVEIRA, C.P.D. da. Manual de inseticidas e acaricidas. Pelotas, Ed. Aimara, 1976. 345p.

CAVERO, E.S. Inseticidas e acaricidas; toxicologia e receituario agronômico. São Paulo, Livroceres, 1982. $412 p$.

COGBURN, R.R. Pirimifos-methyl as a protectant for stored rough rice: small bin tests. Journal of Economic Entomology, Baltimore, 69(3): 369-73, 1976.

COGBURN, R.R.; SIMONAITIS, R.A.; WEBB, B.D. Fate of malathion and chlorphyrifos methyl in rough rice and milling fractions before and after parboiling and cooking. Joumal of Economic Entomology, Baltimore, 83(4): 1636-9, 1990.

CORRAL, F.J.W.; ROCHA, M.O.C.; FLORES, J.B.; ANDRADE, F.B. Insect species infecting grain stored in rural communities in the northeast of Sonora, México. Southwestem Entomologist, College Station, 17(4): 327-31, 1992. Apud Review of Agricultural Entomology. Ser. A, Wallingford, 8(7): 808, Jul., 1993. (Resumo). 
DAVIES, R.A.H. \& DERMARCHELIER, J.M. Combinations of pirimiphos-methyl and carbaryl for stored grain protection. Pesticide Science, Oxford, 12(6): 669-77, 1981.

DEMIANYK, C.J. \& SINHA, R.N. Effect of infestation by the larger grain borer, Prostephanus truncatus (Horn.), and the lesser grain borer, Rhyzopertha dominica (F.) (Coleoptera - Bostrichidae) on stored corn. Environmental Entomology, College Park, 16(3): 618-24, 1987.

DESMARCHELIER, J.M. Selective treatments, including combinations of pyrethroid and organophosphorus insecticides for control of stored product coleoptera at two temperatures. Joumal of Stored Products Research, Elmsfors, 13: 129-37, 1977.

DESMARCHELIER, J.; BENGSTON, M.; CONNELL, M.; MINETT, W.; MOORE, B.; PHILLIPS, M.N.; SNELSON, J.; STICKA, I.; TUCKER, K. A collaborative study of residues on wheat of CGA 20168, chlorpyrifos-methyl, fenitrothion, malathion and pirimiphos-methyl. Part I. Method development. Pesticide Science, Oxford, 8: 473-83, 1977.

FAO/OMS. Evaluacion de los riesgos para el consumidor. In: Reunion conjunta del grupo de trabajo de la FAO sobre resíduos de plaguicidas y del committê de expertos de la OMS em resíduos de plaguicidas. Genebra, 1966. Resíduos de plaguicidas em los alimentos. Informe, Roma, 1967. p.9-13. (FAO: Estudios Agropecuarios, 73. OMS. Série de Informes Técnicos, 370).

FAO/WHO. Report of the 1973. Joint meeting of the FAO Working party of the experts on pesticides and the WHO experts committe on pesticide residues. Geneva, 1974. Pesticide Residues in Food. Informe, Roma, 1974 p. 26-34. (FAO: Agricultural Studies, 92. WHO. Technical Report series, 545). 
FAO/WHO. Report of the 1974. Joint meeting of the FAO Working party of the experts of the pest residues and the WHO experts committee on pesticide residues. Geneva, 1975. Pesticide Residues Food. Informe. Roma, 1975. p.25-30 (FAO. Agricultural Series n.97. WHO Technical Report, Series 574).

FAO. Quarterly bulletin of statistics, Rome, 6(1): 20, 1993.

FARONI, L.R.A. \& GARCIA-MARI, F. Influence of temperature on biological parameters of Rhyzopertha dominica (F.). Boletin de Sanidade vegetal, Plagas, Madrid, 18(2): 455-67, 1992. Apud Review of Agricultural Entomology. Ser. A, Wallingford, 8(7): 733, Jul. 1993. (Resumo).

FIELDS, P.G.; VAN LOON, J.; DOLINSKI, M.G.; HARRIS, J.L.; BURKHOLDER, W.E. The distribution of Rhyzopertha dominica (F.) in Western Canadá. The Canadian Entomologist, Ottawa, 125(2): 317-28, 1993.

FLECHTMANN, C.H.W. Ácaros em produtos armazenados e na poeira domiciliar. Piracicaba, FEALQ, 1986. 97p.

GALLO, D.; NAKANO, O.; SILVEIRA NETO, S.; CARVALHO, R.P.L.; BATISTA, G.C. de; BERTI FILHO, E.; PARRA, J.R.P.; ZUCCHI, R.A.; ALVES, S.B. Manual de entomologia agrícola. São Paulo, Agronômica Ceres, 1988. 649p.

GELMINI, G.A. Agrotóxicos, legislação básica. Campinas, Fundação Cargill, 1991. 2v. $838 p$.

GELMINI, G.A. \& NOVO, J.P.S. Defensivos agricolas; informações básicas e legislação. Campinas, Fundação Cargill, 1987. 577p. 
GIANNOTTI, O. O problema do controle químico e os resíduos de inseticidas. In: CONGRESSO LATINOAMERICANO DE ENTOMOLOGIA, 1., Cuzco, 1971. Anais. Cuzco, 1971. p.47-54.

GUNTHER, F.A. Insecticides residues in California citrus fruits and products. Residue Reviews, Berlin, 28: 1-27, 1969.

HARGREAVES, P.A.; WAINWRIGHT, D.H.; HAMILTON, D.J. A method for the stimation of 1-2-dibromoethane in vegetables. Pesticide Science, Oxford, 5: 225-9, 1974.

HARGREAVES, P.A.; BENGSTON, M.; ALDER, J. Inactivation of deltamethrin on stored wheat. Pesticide Science, Oxford, 13: 639-46, 1982.

HSIEH, F.K.; HSU, S.L.; WU, I.S.; HSIEH, G.C. Toxicity of commonly used insecticides to the maize weevil and lesser grain borer. Plant Protection Bulletin Taiwan, Taichung, 25(4): 285-9, 1983. Apud Review of Applied Entomology. Ser. A, Wallingford, 72(11): 842, Nov. 1984. (Resumo).

JAPAN PESTICIDES INFORMATION. Standards for witholding registration of agricultural chemicals (VIII). Tokyo, 50: 39-41, 1987.

KADOUM, A.M. \& La HUE, D.W. Degradation of malathion of wheat and corn of various moisture contents. Joumal of Economic Entomology, Baltimore, 72(2): 228-9, 1979.

KIRKPATRICK, R.L.; REDLINGER, L.M.; ZETTLER, J.L.; SIMONAITS, R.A. CGA20168 applied to corn for control of stored products insects. Joumal of Economice Entomology, Baltimore, 75: 277-80, 1982. 
KIRKPATRICK, R.L.; REDLINGER, L.M.; SIMONIATIS, R.A.; ZETTLER, J.L. Stability and effectiveness of fenitrothion on corn to control stored-product insects. Joumal of Georgia Entomol. Society, Athens, 18(3): 344-49, 1983.

KORUNIC, Z. \& HAMEL-KOREN, D. The effect of deltamethrin and pirimiphos-methyl on pests of stored products. Zastita Bilja, Serbo-Croatian, 36(4): 417-23, 1985.

La HUE, D.W. Pirimiphos-methyl as a short term protectant of grain against stored products insects. Joumal of Economic Entomology, Baltimore, 68(2): 235-6, 1975.

Le PATOUREL, G. Residues and efficacy of etrinphos, and pirimiphos-methyl in wheat and malting barley stored in ventilated bins. Crop Protection, Oxford, 11(5): 470-6, 1992.

LEVI, I. \& NOWICKI, T.W. Rapid screening method for simultaneous determination of organochlorine and organophosphate pesticide residues in wheat by gas-liquid chromatography. Joumal Association Official Analitical Chemistry, Washington, 57: 944-9, 1974.

LIMA, A.F. de. \& RACCA FILHO, F. Pragas e praguicidas; dicionário; aspectos legais, toxicológicos e recomendações técnicas. Rio de Janeiro, 1987. 126p.

LOPES, D.C.; ANDRADE FONTES, R. de; DONZELE, J.L.; ALVARENGA, J.C. Perda de peso e mudanças na composição química do milho (Zea mays L.) devido ao carunchamento. Revista da Sociedade Brasileira Zootecnia, Viçosa, 17(4): 367-71, 1988. 
LORINI, I. \& SCHNEIDER, S. Eficiência do inseticida deltametrina aplicado em grãos de trigo armazenado para controle de Rhyzopertha dominica (Fabricius, 1792) (Col., Bostricidae). In: CONGRESSO BRASILEIRO DE ENTOMOLOGIA, 14., Piracicaba, 1993. Resumos. Piracicaba, FEALQ, 1993. p.539.

McGAUGEY, W. Malathion on milling fractions of three varieties of rough rice: duration of protection and residue degradation. Joumal of Economic Entomology, Baltimore, 64(5): 1200-5, 1971.

MENSAH, G.W.K.; WATTERS, F.L.; WEBSTER, G.R.B. Insecticide residues in milled fractions of dry tough wheat treated with malathion, bromophos, iodofenphos and pirimiphos-methyl. Joumal of Economic Entomology, Baltimore, 72: 728-31, 1979.

MESTRES, R.; CHEVALIER, C.; ESPINOSA, C.; CORNET, R. Dosage des résidus de décamethrine dans les produts végétaux. Travaux de la Société de Phamacie de Montpellier, Montpellier, 38(2): 183-92, 1978.

MESTRES, R.; ESPINOSA, C.; CHEVALIER, C.; MARTI, G. Note sur l'analyse des résidus de décamethrine. Travaux de la Société de Phamacie de Montpellier, Montpellier, 39(4): 329-36, 1979.

MUCCIO, A. de; AUSKI, A.; VERGORI, L.; CAMONI, I; DOMMARCO, R.; GAMBETTI, L. Single-step multi-cartridge clean-up for organophosphate pesticide residue determination in vegetable-oil extracts by gas chromatography. Analist, London, 115: 1167-9, 1990.

NAKANO, O.; SILVEIRA NETO, S.; BATISTA, G.C. de; YOKOYAMA, M.; DEGASPARI, N.; MARCHINI, L.C. Manual de inseticidas; dicionário. São Paulo, Agronômica Ceres, 1977. 272p. 
NOBLE, R.M.; HAMILTON, D.J.; OSBORNE, W.J. Stability of pyrethroids on wheat in storage. Pesticide Science, Oxford, 13: 246-52, 1982.

PIZANO, M.A. Resíduos de bromopropilato e clorobenzilato em cascas e polpas de laranjas "Valencia" determinados por cromatografia em fase gasosa. Piracicaba, 1988. 101p. (Mestrado - Escola Superior de Agricultura "Luiz de Queiroz"/USP).

RANZAN, M. \& CHAHAL, B.S. Evaluation of synthetic pyrethroids for the protection of stored wheat grains against stored pests. International Pest Control, London, 29(2): 42-4, 1987.

REZENDE, A.C.; ISHIZAKI, T.; NOVAES, D.F.; LAZZARINI, S.; MIIKE, H.L. Avaliação prática de K-obiol no tratamento de grãos armazenados em armazéns graneleiros. In: CONGRESSO BRASILEIRO DE ENTOMOLOGIA, 9, Londrina, 1984. Resumos. Londrina, SEB, 1984. p.251.

RIGITANO, R.L.O. Resíduos de ethion e fenitrotion em cascas e polpas de laranjas Hamlin determinadas por cromatografia em fase gasosa. Piracicaba, 1979. 64p. (Mestrado - Escola Superior de Agricultura "Luiz de Queiroz"/USP).

ROJAS-LEÓN, J.C. Notas sobre los insetos que danan al maiz almacenado en "La Frailesca", Chiapas, Mexico. Folia Entomologica Mexicana, Mexico, 76: 187-93, 1988.

ROWLANDS, D.G. The metabolism of contact insecticides in stored grains. Residue Reviews, Berlin, 17: 105-77, 1967.

SAMSON, P.R. \& PARKER, R.J. Laboratory studies on protectants for control of coleoptera in maize. Joumal of Stored Products Research, Elmsfors, 25(1): 49-55, 1989. 
SANTOS, J.P. \& WAQUIL, J.M. Controle dos principais coleopteros pragas do trigo durante o armazenamento. In: CONGRESSO BRASILEIRO DE ENTOMOLOGIA, 14; Piracicaba, 1993. Resumos. Piracicaba, FEALQ, 1993. p.534.

SATTIGI, H.N.; KULKARNI, K.A.; THONTADARYA, T.S. Studies on the biology of lesser grain borer on sorghum under laboratory conditions. Joumal of Maharashita Agricultural Universities, Pune, 10(3): 252-4, 1985. Apud Review of Applied

Entomology, Ser. A, Wallingford, 74(18): 439, 1986. (Resumo)

SCHROTER, R.A.; GONSALVES, R.; PEREZ, C.A.; NAKANO, O. Ação curativa do Kobiol 25 CE sobre Rhyzopertha dominica (Fabr., 1792) (Col. - Bostrichidae) em grãos de trigo armazenados. In: CONGRESSO BRASILEIRO DE ENTOMOLOGIA, 13., Recife, 1991. Resumos. Recife, SEB, 1991. p.465.

SKARIA, B.P.; NADARAJAN, L.; NAIR, R. Efficacy of deltamethrin against pest of stored rice by direct spraying. Oryza, Cuttack, 26(3): 320-2, 1989.

SODERLAND, D.M. \& CASSIDA, J.E. In: Synthetic pyrethroids. Washington, (HCS Symposium, series, 42). American Chemical Society Washington, 1977. p.162.

SOWUNMI, O.E. \& FETUGA, B.L. The degradation of pirimiphos-methyl applied to stored yelow maize in the hot humid tropic. Bulletin of grain technology, Uttar Pradesh, 21(2): 105-9, 1985. Apud Review of Applied Entomology, Ser. A., Wallingford, 74(2): 61, Feb. 1986. (Resumo).

STORRHER, R.W.; OTT, P.; WATTS, R.R. A general method for organophosphorus pesticide residues in nonfatty foods. Joumal Association Official Analitical Chemistry, Washington, 54(3): 513-24, 1971. 
TOMIZAWA, C. Past and present status of residues of pesticides manufactured in Japan. Japan Pesticide Information, Tokyo, 30: 5-42, 1977.

WHITE, N.D.G. \& ABRAMSON, D. Uptake of malathion from galvanized - steel surfaces by stored barley. Joumal of Economic Entomology, Baltimore, 77: 289-93, 1984.

WORLD HEALTH ORGANIZATION. Evaluations of some pesticide residue in food. Geneva, FAO; WHO, 1975. 545p. (WHO Pesticide Residues Série, 4). 